\title{
Molecular identification and morphological description of Theloderma albopunctatum tadpoles from the Phu Khiao-Nam Nao Forest Complex, northeastern Thailand
}

\author{
JIDAPA CHUNSKUL ${ }^{1}$, PRAPAIPORN THONGPROH ${ }^{1}$, WANCHAI SIMMASIAN ${ }^{2}$, JIRACHAI ARKAJAG ${ }^{3}$, \\ SATAPHON TONGPUN ${ }^{3}$, PERMSAK KANISHTHAJATA ${ }^{4}$, SUTHIN PROMPALAD ${ }^{5}$, SUTEE DUANGJAI ${ }^{6}$, \\ PRATEEP DUENGKAE ${ }^{6}$, RATCHATA PHOCHAYAVANICH ${ }^{7}$, CHANTIP CHUAYNKERN $^{1}$, \\ YODCHAIY CHUAYNKERN ${ }^{1, v}$ \\ ${ }^{1}$ Department of Biology, Faculty of Science, Khon Kaen University. Mueang Khon Kaen, Khon Kaen, 40002 Thailand. \\ Tel.: +68-6005-2507, "email: yodchaiy@kku.ac.th \\ ${ }^{2}$ Phu Luang Wildlife Sanctuary. Phu Rue, Loei, 42160, Thailand \\ ${ }^{3}$ Phu Luang Wildlife Research Station. Phu Rue, Loei, 42160, Thailand \\ ${ }^{4}$ Huai Kha Khaeng Wildlife Sanctuary. Lan Sak, Uthai Thani, 61160, Thailand \\ ${ }^{5}$ Nam Nao National Park. Nam Nao, Phetchabun, 67260, Thailand \\ ${ }^{6}$ Department of Forest Biology, Faculty of Forestry, Kasetsart University. Chatuchak, Bangkok, 10900 Thailand \\ ${ }^{7}$ Faculty of Interdisciplinary Studies, Khon Kaen University. Nongkhai Campus, Nong Khai 43000, Thailand
}

Manuscript received: 27 July 2021. Revision accepted: 29 October 2021.

\begin{abstract}
Chunskul J, Thongproh P, Simmasian W, Arkajag J, Tongpun S, Kanishthajata P, Prompalad S, Duangjai S, Duengkae P, Phochayavanich R, Chuaynkern C, Chuaynkern Y. 2021. Molecular identification and morphological description of Theloderma albopunctatum tadpoles from the Phu Khiao-Nam Nao Forest Complex, northeastern Thailand. Biodiversitas 22: 5145-5161. Presently, tadpole description of an external morphology and internal oral features of Theloderma albopunctatum (Anura, Rhacophoridae) is unknown. Therefore, this study aimed to describe tadpoles of T. albopunctatum from the Phu Khiao-Nam Nao Forest Complex in northeastern Thailand based molecular and morphological characters. Tadpole identification was based on molecular analyses. The 16S and COI sequences of the T. albopunctutatum tadpole had a genetic distance of $0 \%$ and $0.15 \%$ with the adults from Phu Luang Wildlife Sanctuary and Nam Nao National Park, respectively. Bayesian inference analyses of 16S, 16S+COI, and BDNF + SIA + RHO + TYR strongly supported the identity of tadpole and adults $T$. albopunctatum tadpoles are of medium size, with a black to ashy gray body that turns dark brown in preservative, they also exhibit elliptical body depressions and follow the keratodont row formula $1: 2+2 / 1+1: 2$ or 1:1+1/1+1:1. T. albopunctatum tadpoles are generally similar to T. asperum.
\end{abstract}

Keywords: DNA, morphology, SEM, DNA, tadpole, Theloderma albopunctatum

\section{INTRODUCTION}

Theloderma Tschudi 1838 (type species: Theloderma leporosa Tschudi 1838) is a genus in the family Rhacophoridae that is distributed from northeastern India to Myanmar, as well as from southern China southward through Indochina to Malaysia and Indonesia (Frost 2021). Morphologically, Theloderma species exhibit high degrees of similarity (Nguyen et al. 2014; Poyarkov et al. 2015; Nguyen et al. 2016; Dever 2017). Although many studies have attempted to delimit Theloderma species based on morphological characteristics (Dever 2017), none has formed a morphological synapomorphy for the genus. Therefore, the monophyly of Theloderma remains in question (Wilkinson and Drewes 2000; Wilkinson et al. 2002; McLeod and Norhayati 2007; Yu et al. 2007; Yu et al. 2008; Li et al. 2008; Bain et al. 2009; Li et al. 2009; Rowley et al. 2011; Li et al. 2013; Dever et al. 2015).

At present, Theloderma consists of 26 species, 7 species of which are known from Thailand, namely $T$. albopunctatum (Liu and Hu 1962), T. asperum (Boulenger 1886), T. gordoni Taylor, 1962, T. horridum (Boulenger
1903), T. licin McLeod and Norhayati 2007, T. petilum (Stuart and Heatwole 2004), and T. stellatum (Taylor 1962) (Frost 2021). However, Dever (2017) first listed $T$. vietnamense (Poyarkov et al. 2015) in Thailand based on the 16S rRNA gene analysis of specimen from Mae Yom (KUHE 22065). Later work, Niyomwan et al. (2019) included $T$. vietnamense in the list of amphibians in Thailand. Further, T. phrynoderma (Ahl, 1927) was also listed for the first time. Therefore, a total of nine Theloderma species had previously been reported (Taylor 1962; McLeod and Norhayati 2007; Poyarkov et al. 2015; Dever 2017; Phusaensri et al. 2018; Niyomwan et al. 2019), namely $T$. albopunctatum, T. asperum, T. gordoni, T. horridum, T. licin, T. petilum, T. stellatum, $T$. vietnamense, and T. phrynoderma.

Theloderma bicolor (Bourret 1937) was the first Theloderma (as Rhacophorus leprosus bicolor) described from "Chapa" (=Sa Pa), Lao Cai Province, Vietnam. Later, some new species were described as new to science (see Frost 2021). From 1938 to 1962, a total of 11 Theloderma were discovered. Lastly, 14 species were added during 2004 to the present. As the monophyly of the Theloderma 
still unclear and requires further intensive studies of morphology and molecular data. Nguyen et al. (2015) analyzed 2412 bp combined sequences of $12 \mathrm{~S}$ rRNA, tRNA $^{\mathrm{val}}$, and $16 \mathrm{~S}$ rRNA. The phylogenetic relationship based on a maximum likelihood tree showed that $T$. moloch was not inside of Theloderma. This result is similar to Poyarkov et al. (2015) who analyzed 1987 bp combined sequences of $12 \mathrm{~S}$ rRNA $+16 \mathrm{~S}$ rRNA. Monophyly of the Theloderma (excluding T. moloch) and Nyctixalus was strongly supported in Nguyen et al. (2015). By excluding $T$. moloch, T. horridum group (T. horridum, T. stellatum, and $T$. vietnamense) and Nyctixalus (as $T$. pictum), the monophyly of the clade comprising other Theloderma members. Poyarkov et al. (2015) reduced Nyctixalus to subgeneric level of Theloderma and established a new subgenus Stelladerma for $T$. horridum $+T$. stellatum group (T. stellatum and $T$ vietnamense). The remaining Theloderma, clade A in Nguyen et al. (2015) was separated into two subclades (subclades A and B). Poyarkov et al. (2015) suggested that the remaining Theloderma consists of two major groups. The first group, namely $T$. asperum group contained $T$. ryabovi, $T$. albopunctatum, $T$. petilum, T. licin, and T. asperum. Members of this group are small to large-sized, presence of vocal sac opening and uniform reddish-brown iris and large white blotches on the rear part of the dorsum (absence for T. petilum) (Nguyen et al. 2015; Poyarkov et al. 2015). The second group was divided into two subgroups, namely $T$. leporosum group (T. corticale, $T$. bicolor, T. rhododiscum, T. leporosum, T. gordoni, and $T$. palliatum) and T. laeve group (T. laeve, T. nebulosum, $T$. truongsonense, $T$. cf. truongsonense [from central Vietnam], and Theloderma sp. [from South Vietnam]). Members of the $T$. laeve group join small-sized Theloderma taxa from southern and central Vietnam and two unidentified lineages allied to $T$. truongsonense. Members of $T$. leporosum join all other large-sized Theloderma species. However, phylogenetic constructing within $T$. laeve and $T$. leporosum groups received low support and relationships between members of these groups remain sufficiently unresolved and require further study. Therefore, Sivongxay et al. (2016) rejected this proposal and, maintained Theloderma and Nyctixalus as separate genera. In particular T. asperum group of Poyarkov et al. (2015), four species have been recorded in Thailand, namely $T$. albopunctatum, T. petilum, T. licin, and $T$. asperum. Among them, T. albopunctatum and T. asperum are highly similar in appearance and size (Dever 2017) and their tadpole are known only for $T$. asperum (Leong and Lim 2003).

Voucher specimens of Theloderma are rare in herpetological collections, sometimes consisting of a single sex or single age (Dever 2017). Theloderma tadpoles are virtually unknown from Thailand. They have been reported only by Wassersug et al. (1981), who described the buccal morphology of T. stellatum based on six tadpole specimens from Khao Soi Dao Wildlife Sanctuary in Chanthaburi Province, southeastern Thailand. To fill this gap in knowledge regarding Theloderma species, the present study aimed to describe $T$. albopunctatum tadpole specimens based on molecular and morphological analyses.

\section{MATERIALS AND METHODS}

\section{Study area}

The Phu Khieo-Nam Nao Forest Complex (PKNNFC) is located in the Phetchabun mountain range of northeastern Thailand $\left(15^{\circ} 19^{\prime} 18^{\prime \prime}-17^{\circ} 33^{\prime} 00^{\prime \prime} \mathrm{N}, 101^{\circ} 16^{\prime} 00^{\prime \prime}-\right.$ $102^{\circ} 43^{\prime} 50^{\prime \prime E}$, altitude 150-1,571 m asl) (Figure 1) (Division of Information System on Wildlife Conservation 2020). The PKNNFC lies in the Phetchabun mountain range and covers an area of approximately $7,990.5 \mathrm{~km}^{2}$ in Loei, Phetchabun, Khon Kaen, Chaiyaphum, Nong Bua Lam Phu, and Lop Buri Provinces. The PKNNFC contains 13 national parks and seven wildlife sanctuaries. The vegetation types are mixed deciduous forest, dry evergreen forest, dry dipterocarp forest, hill evergreen forest, pine forest, and savanna forest. The PKNNFC has a tropical monsoonal climate with distinct long rainy (mid-May to mid-October), winter (from mid-October to mid-February), and summer seasons (mid-February to mid-May). The average of annual rainfall and temperature ranges from $1,123-1,238 \mathrm{~mm}$ and $26.0-27.4^{\circ} \mathrm{C}$, respectively. The average annual maximum temperature is between 32.0$33.2^{\circ} \mathrm{C}$, while the minimum is $20.1-22.2^{\circ} \mathrm{C}$ (Department of National Parks, Wildlife and Plant Conservation 2014).

Field surveys were conducted in four protected areas within the PKNNFC, including Nam Nao National Park (Phetchabun Province), Phu Wiang National Park (Khon Kaen Province), Phu Luang Wildlife Sanctuary (Loei Province), and Phu Khieo Wildlife Sanctuary (Chaiyaphum Province).

\section{Research materials}

Permission to conduct research was granted by the Department of National Parks, Wildlife and Plant Conservation, Thailand (nos. 0907.4/15590 and 0907.4/22080). This research was reviewed and approved by the Institutional Animal Care and Use Committee of Khon Kaen University, based on the Ethics of Animal Experimentation guidelines of the National Research Council of Thailand (No. 660201.2.11/67).

Nine tadpoles (PT 2499.1-9) were collected in stagnant water of an old disused toilet in a dry evergreen forest nearby the second check point $\left(17^{\circ} 20^{\prime} 5^{\prime \prime} \mathrm{N}, 101^{\circ} 30^{\prime} 32^{\prime \prime} \mathrm{E}\right.$, altitude $940 \mathrm{~m}$ asl). These tadpoles were euthanized by immersion in chlorobutanol. A portion of the tail was cut from each selected specimen (PT 2499.1) for molecular analysis. The specimen (the DNA voucher) was used for detailed description. The remaining parts of the tadpoles and other specimens were preserved in a solution containing equal parts $10 \%$ formalin and $70 \%$ ethanol (Chuaynkern et al. 2019).

Two adult specimens were used in this study. The first adult male (JC 02506) was collected along with the tadpoles at the same locality. The second adult female (PT 02378) was collected from the toilet at the headquarter of the Nam Nao National Park $\left(16^{\circ} 44^{\prime} 279^{\prime \prime N}, 101^{\circ} 34^{\prime} 16^{\prime \prime E}\right.$, altitude $842 \mathrm{~m} \mathrm{asl}$ ). These frogs were euthanized by immersion in chlorobutanol, pieces of the liver were cut and preserved in $70 \%$ ethanol. The specimens were later fixed in $10 \%$ formalin and transferred for preservation in 
70\% ethanol. All larval and adult specimens were cataloged and deposited in the Thailand Natural History Museum (THNHM), National Science Museum, (Pathum Thani Province, central Thailand).

\section{Molecular study}

Tissue samples of livers (PT 02378 and JC 02506) and the tail portion (PT 02499.1) were used for DNA extraction. Total genomic DNA was extracted using the GF-1 Tissue DNA Extraction Kit (Vivantis, Inc.). Fragments of mtDNA 16S rRNA (16S), cytochrome oxidase subunit I (COI), nuDNA brain-derived neurotrophic factor (BDNF), rhodopsin (RHO), seventh-inabsentia (SIA), and tyrosinase (TYR) genes were amplified by polymerase chain reaction (PCR) as described by Dever (2017), using the same primers (Table 1) and modified PCR conditions as follows: 1 cycle initial denaturation at $94^{\circ} \mathrm{C}$ for $4 \mathrm{~min}, 33$ cycles of denaturation at $94^{\circ} \mathrm{C}$ for $30 \mathrm{~s}$, annealing at $72^{\circ} \mathrm{C}$ for $1 \mathrm{~min}$, extension at $72^{\circ} \mathrm{C}$ for $7 \mathrm{~min}$, and 1 cycle final extension at $72^{\circ} \mathrm{C}$ for $7 \mathrm{~min}$. For $\mathrm{COI}$ condition: 1 cycle initial denaturation at $94^{\circ} \mathrm{C}$ for $45 \mathrm{~min}$, 35 cycles of denaturation at $60^{\circ} \mathrm{C}$ for $30 \mathrm{~s}$, annealing at $72^{\circ} \mathrm{C}$ for $45 \mathrm{~s}$, extension at $72^{\circ} \mathrm{C}$ for $7 \mathrm{~min}, 1$ cycle final extension at $72^{\circ} \mathrm{C}$ for $7 \mathrm{~min}$. The PCR products were purified and sequenced by Macrogen Co., Ltd. (Seoul, South Korea).

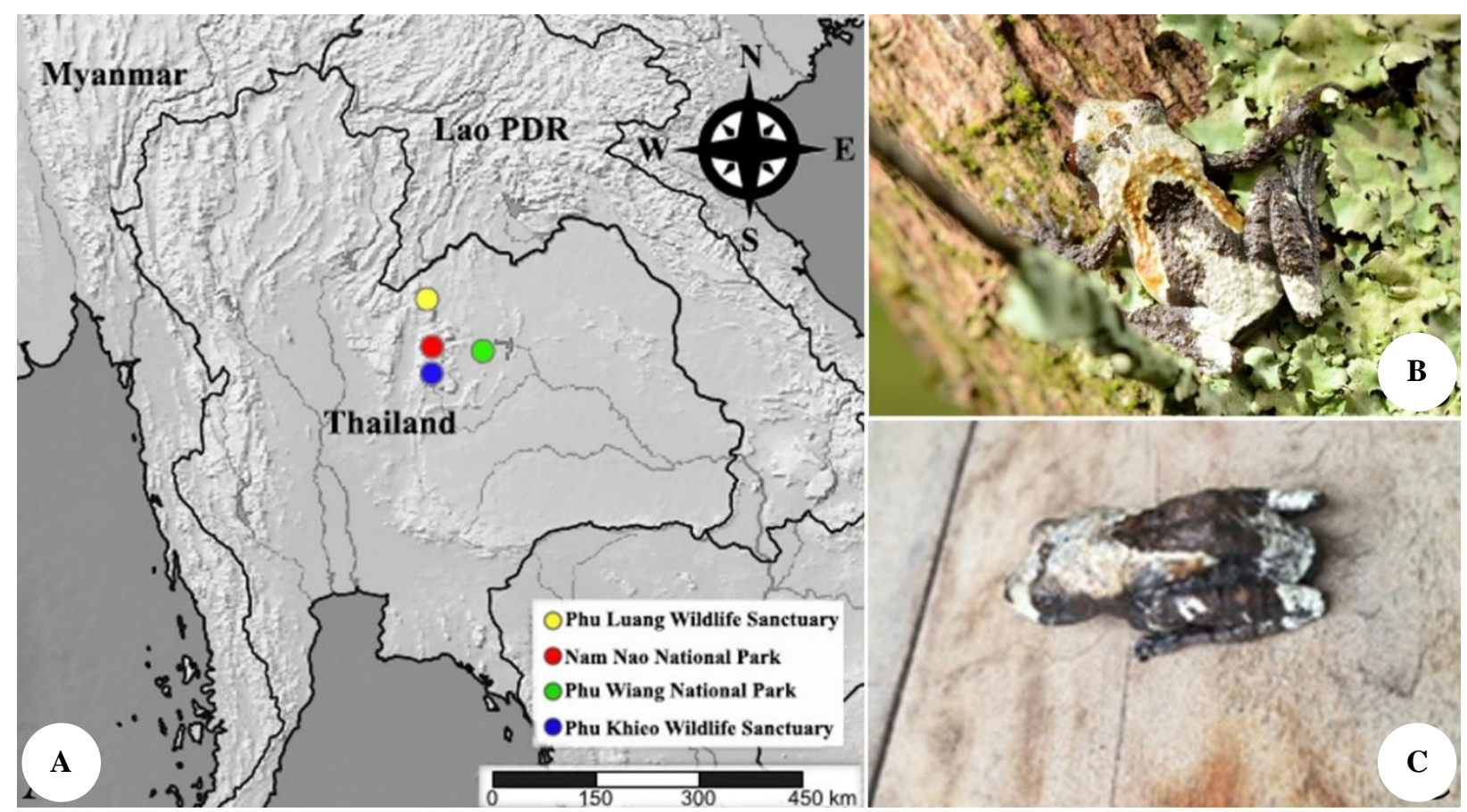

Figure 1. Location of the Phu Khieo-Nam Nao Forest complex, northeastern Thailand. A. Map showing four protected areas, B. Theloderma albopunctatum from Phu Luang Wildlife Sanctuary (PT JC 02506, SVL $30.3 \mathrm{~mm}$ ), C. Theloderma albopunctatum from Nam Nao National Park (PT 02378, SVL 32.4 mm)

Table 1. Primers used for amplification of the markers analyzed in this study

\begin{tabular}{|c|c|c|c|}
\hline Marker & Primer & Primer sequence $\left(5^{\prime}-3^{\prime}\right)$ & Source \\
\hline \multirow[t]{2}{*}{$\overline{\mathrm{COI}}$} & AH-CO1A-S & CTACAAYCCRCCRCCTRCTCGGCCAC & Grosjean et al. (2015) \\
\hline & AH-CO1A-AS1 & TADACYTCDGGRTGDCCAAARAATCA & \\
\hline \multirow[t]{2}{*}{$16 \mathrm{~S}$} & $16 \mathrm{SaL}$ & TADACYTCDGGRTGDCCAAARAATCA & Palumbi et al. (1991) \\
\hline & $16 \mathrm{SbH}$ & CCGGTCTGAACTCAGATCACGT & \\
\hline \multirow[t]{2}{*}{ BNDF } & BNDF-F & GACCATCCTTTTCCTKACTATGGT TATTTCATACTT & Noonan and Chippindale (2006) \\
\hline & BNDF-R & СТАTСТTССССТTTTAATGGTCAGTGTACAAAC & \\
\hline \multirow[t]{2}{*}{ RHO } & Rhod1A & ACCATGAACGGAACAGAAGGYCC & Bossuyt and Milinkovitch (2000) \\
\hline & Rhod1D & GTAGCGAAGAARCCTTCAAMGTA & \\
\hline \multirow[t]{2}{*}{ SIA } & SIA1(T3) & TCGAGTGCCCCGTGTGYTTYGAYTA & Bonacum et al. (2001) \\
\hline & SIA2(T7) & GAAGTGGAAGCCGAAGCAGSWYTGCATCAT & \\
\hline \multirow[t]{2}{*}{ TYR } & Tyr1A & AGGTCCTCTTRAGCAAGGAATG & Bossuyt and Milinkovitch (2000) \\
\hline & Tyr1G & TGCTGGGCRTCTCTCCARTCCCA & \\
\hline
\end{tabular}




\section{Morphological study}

The tadpole morphological terminology used in this study follows Altig and McDiarmid (1999), the keratodont row formula (KRF) follows Dubois (1994), and the developmental stages follow Gosner (1960). Most measurements were acquired using a digital caliper; measurements smaller than $1 \mathrm{~mm}$ were acquired using an ocular micrometer attached to a stereomicroscope. In total, 23 measurements were used in this study: distance from tip of snout-insertion to spiracle opening (SS), distance from tip of snout-insertion to upper tail fin (SU), body length (BL), tail length (TAL), total length (TL), maximum upper fin height (UF), maximum lower fin height (LF), maximum tail height $(\mathrm{MTH})$, body height $(\mathrm{BH})$, maximum body width (BW), maximum tail muscle height (TMH), tail muscle width at the end of body (TMW), interpupillary distance (PP), internarial distance (NN), rostro-narial distance (RN), naro-pupillary distance (NP), maximum eye diameter (ED), nostril diameter (ND), spiracle diameter $(\mathrm{SD})$, anterior labium (AL), posterior labium (PL), oral disc width (ODW), and maximum size of dorsal papilla gap (DG). Tadpole photographs were taken using a digital camera, whereas the oral disc used a digital camera attached to a stereomicroscope. Larval photographs were acquired under a stereomicroscope.

The mouthparts of selected tadpoles were prepared for scanning electron microscopy (SEM) examination at the Faculty of Science, Khon Kaen University, Khon Kaen, northeastern Thailand. The mouthparts were cut into two pieces (roof and floor) using surgical scissors. The roof and floor were wrapped with straining cloth and dehydrated by soaking in a series of ethanol solutions $(70 \%, 90 \%$, and $100 \%, 24 \mathrm{~h}$ per concentration). The materials were soaked for 20 minutes in a solution containing equal parts ethanol and amyl acetate, followed by soaking for 20 minutes in amyl acetate and drying in a critical-point dryer (Quorum K850, Quorum Technologies, UK). The materials were then attached to an SEM stub and coated with heavy metals for SEM photography using a DMS 950 scanning electron microscope (Zeiss, Oberkochen, Germany) at $10 \mathrm{kV}$. The SEM photographs were used for observing buccal features in detail. Terminology of the buccal features follows Wassersug (1976). The resulting images were modified using Adobe Photoshop software.

\section{Data analysis}

The sequences were edited using DNA Dragon software (Hepperle 2011) and aligned using the SeaView v4 tool (Gouy et al. 2010) or the Mesquite v3.61 tool for multiple alignments (Maddison and Maddison 2019). The available $16 \mathrm{~S}$ and COI GenBank sequences covering all Theloderma species and their closest rhacophorid relatives were used as described by Dever (2017). Phylogenetic trees were determined separately for $16 \mathrm{~S}$, concatenated mtDNA, and concatenated nuDNA via Bayesian inference analyses using the CIPRES Science Gateway (Miller et al. 2010) and the MrBayes software, run on the XSEDE v3.2.7a platform, and Markov chain Monte Carlo analysis for $10,000,000$ generations, with the initial 250,000 trees (25\%) discarded as burn-in. Posterior Bayesian credibility values for each branch in a 50\% majority-rule consensus tree were calculated. The evolution model was selected using the MrModeltest v2.4 software (Nylander 2004); the best-fitting mtDNA and nuDNA models were GTR+I+G and $\mathrm{K} 80+\mathrm{I}+\mathrm{G}$, respectively. Uncorrected pairwise distances (p) for the $16 \mathrm{~S}$ and COI fragments were calculated using CIPRES and the results were used analyzed using a phylogenetic tree in accordance with the PAUP* method (Swofford 2019). The available sequence data for Theloderma species and their closest rhacophorid relatives were downloaded from GenBank. Buergeria oxycephala of the subfamily Buergiinae is a basal lineage of the subfamily Rhacophorinae (Wilkinson et al. 2002; Li et al. 2009) was chosen as the outgroup. Voucher specimens, localities, and GenBank numbers for all samples used in this study are presented as supplementary file (Table S1). Measurements of tadpoles were calculated an average value for the tadpoles in stage 25 ( 7 tadpoles) as presented in Table 3.

\section{RESULTS AND DISCUSSION}

\section{Molecular analysis}

The obtained mtDNA fragments consisted of a 1,235bp region, and the obtained nuDNA fragments consisted of an 1,854-bp region. The $16 \mathrm{~S}$ gene sequences contained 520 bp (46 variable and 253 informative sites), and the COI gene contained 715 bp (22 variable and 286 informative sites). Bayesian inference analyses based on the $16 \mathrm{~S}$ matrix strongly supported the identity of PKNNFC specimens (BPP: 1) nested in group A of the T. albopunctatum clade (Figure 2). Based on 16S+COI analyses, PKNNFC specimens remained nested in the T. albopunctatum clade (Figure 3; BPP: 1). Genetic distances based on the $16 \mathrm{~S}$ (mean, 0.07) and COI (mean, 0.10) genes between PKNNFC specimens and specimens of closely related species are shown in Table 2. Based on the BDNF+SIA+RHO+TYR matrix, PKNNFC specimens were nested in the T. albopunctatum clade (Figure 4; BPP: 0.88). Therefore, we assigned PKNNFC specimens to $T$. albopunctatum based on Bayesian inference analyses of mtDNA (16S and 16S+COI) and nuDNA (BDNF+SIA+RHO+TYR).

The sequences of the tadpole (PT 02499.1) and the adult specimen (JC 02506) from Phu Luang Wildlife Sanctuary had a genetic distance of $0 \%$ (16S and COI). Whereas the genetic distances between the tadpole and adult specimen from Nam Nao National Park (PT 02378) were $0 \%$ and $0.15 \%$ for $16 \mathrm{~S}$ and COI, respectively (Table 2). 


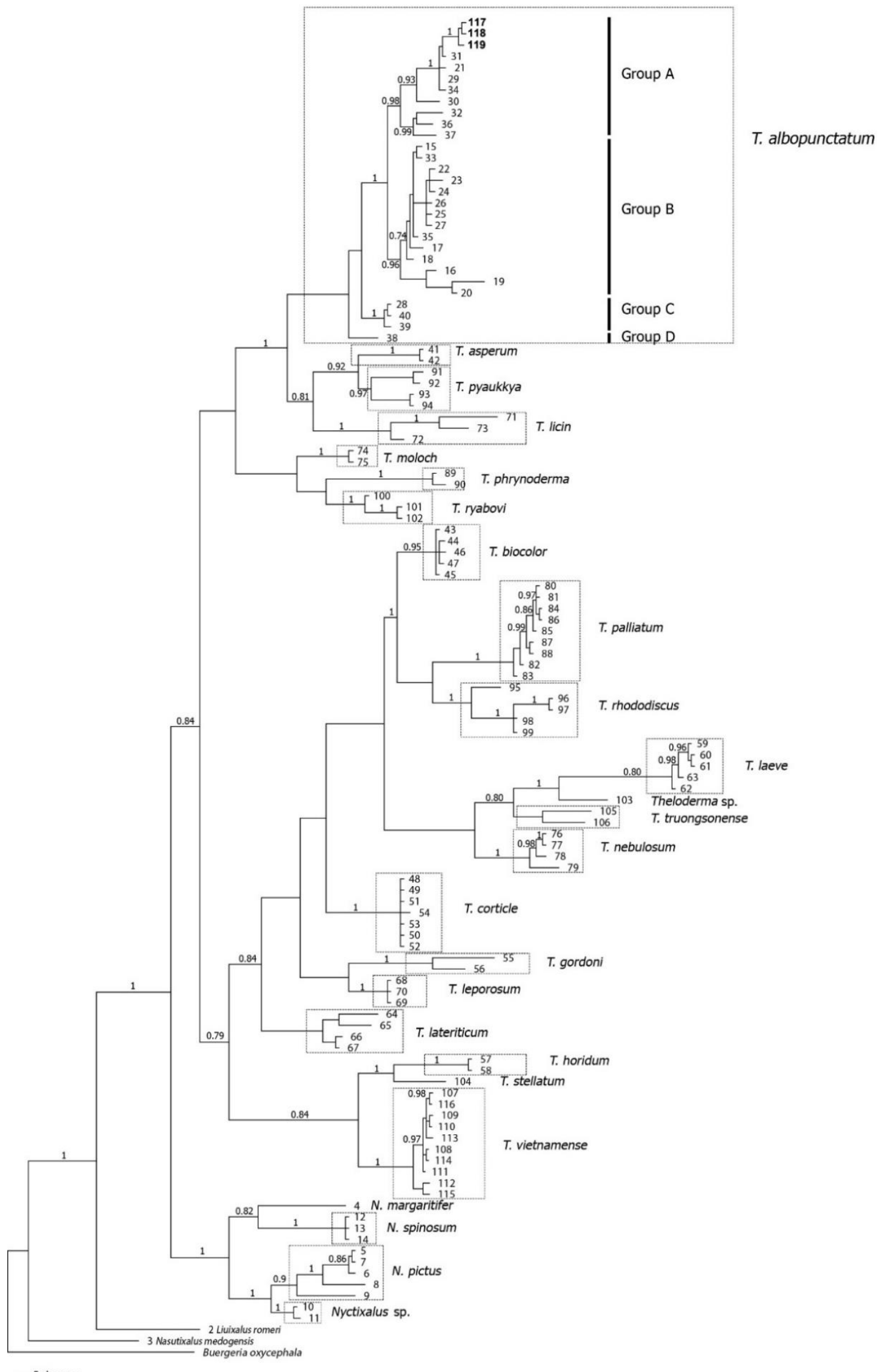

Figure 2. Phylogenetic tree constructed from partial DNA sequences of the 16S rRNA gene based on Bayesian analysis. Numbers above branches are Bayesian posterior probabilities $\geq 70 \%$. Voucher specimens and GenBank accession numbers are given in the supplementary table (Table S1). Numbers of specimens (No. 1-119) correspond to those in Table S1. The bold numbers of specimens (No. 117-119) indicate new materials from this study 


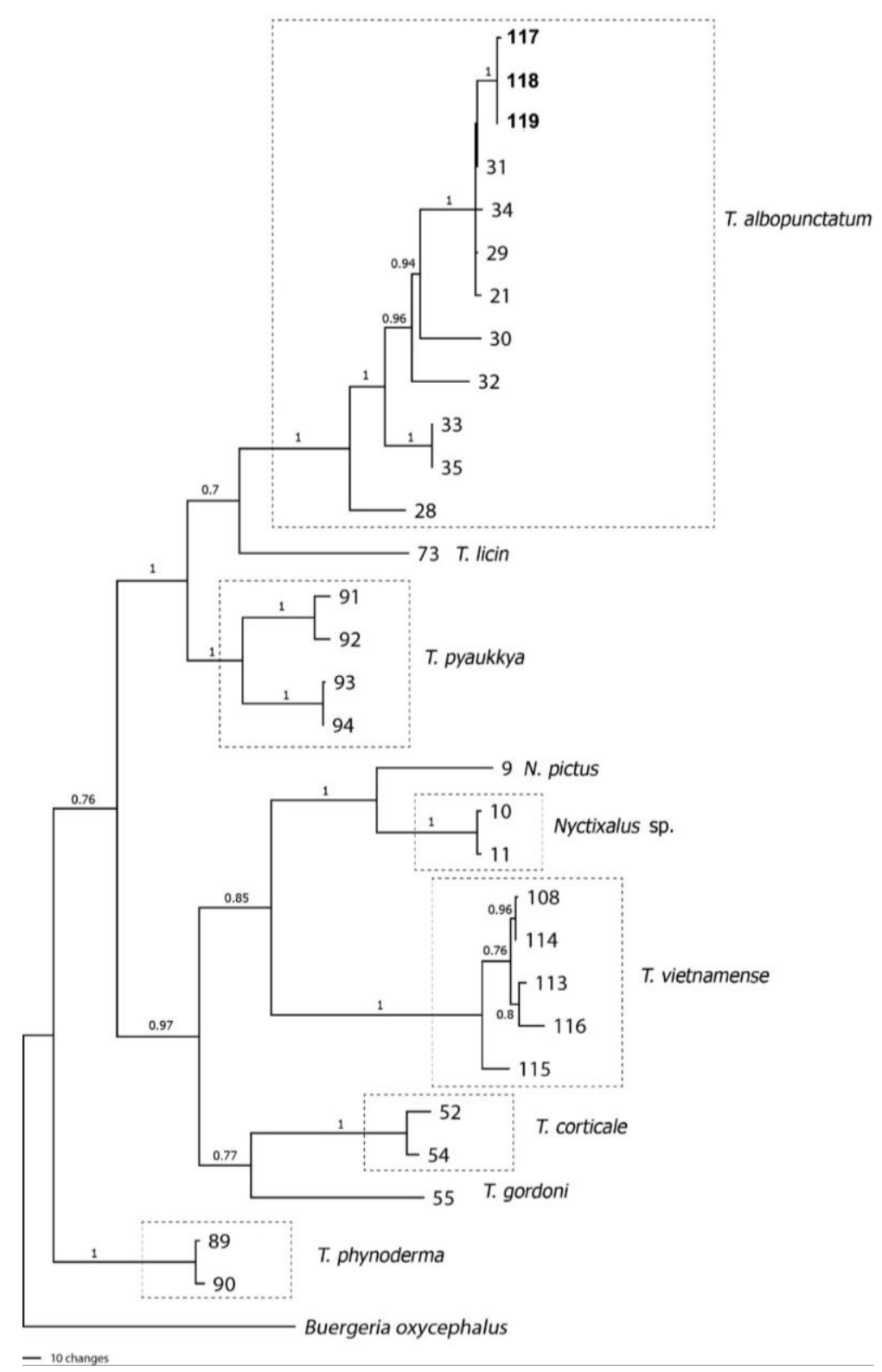

Figure 3. Phylogenetic tree constructed from partial DNA sequences of the concatenated 16S fragment and COI gene based on Bayesian analysis. Numbers above branches are Bayesian posterior probabilities $\geq 70 \%$. Voucher specimens and GenBank accession numbers are given in the supplementary table (Table S1). Numbers of specimens (No. 1-119) correspond to those in Table S1. The bold numbers of specimens (No. 117-119) indicate new materials from this study

\section{Morphological description}

A total of nine tadpoles were used in the present work. Variation of these tadpoles was assessed based on three stages distributed in stages $25(78 \%), 27(11 \%)$, and 37 $(11 \%)$. The BL and TAL (excluded PT02499.1) are 5.4$15.4 \mathrm{~mm}$ and 9.8-25.2 mm, respectively. The tadpoles of $T$. albopunctatum are medium size with a maximum total length $38.9 \mathrm{~mm}$ in stage 37 . Different collective KRF can be found: $1: 1+1 / 1+1: 2(78 \%)$ and $1: 2+2 / 1+1: 2(22 \%)$. The ratios of BW $120-177 \%$ of $\mathrm{BH}$; ED $4-9 \%$ of BL; RN $33-$ $91 \%$ of NP; NN $52-94 \%$ of PP; SS $68-83 \%$ of BL; TMH $37-57 \%$ of BH; TMH 31-65\% of MTH; TMW $17-37 \%$ of BW; UF 24-37\% of MTH; LF 19-34\% of MTH; SU 86$96 \%$ of BL; MTH $80-140 \%$ of BH; ODW $14-26 \%$ of BL; ODW $18-42 \%$ of BW; and DG $69-127 \%$ of ODW (Table 3 ).

\section{Larval description}

Larval description is based on $T$. albopunctatum specimen, namely PT 02499.1, Gosner stage 27, TL 13.6 $\mathrm{mm}$ (cut tail), BL $11.4 \mathrm{~mm}$. Body in lateral view elliptical, snout oval (Figure 5A); body in dorsal view oval, snout narrow and oval (Figure 5B); BW $120 \%$ of BH. Eyes moderately large, ED 5\% of BL, slightly bulging and not visible in ventral view, positioned dorsally, directed dorsolaterally. Nares small, round, rimmed, positioned and directed dorsally, closer to tip of snout than to pupils, RN $41 \%$ of NP; NN $72 \%$ of PP. Spiracle single, sinistral, square, medium-sized, at $2 / 3$ the distance between snout and anal tube opening; in lateroventral position, oriented postero-ventrally, free from body over most of its length; SS $68 \%$ of BL; spiracle opening oval, opening situated at 
hind limb level. Tail musculature strong, TMH $44 \%$ of $\mathrm{BH}$ and $55 \%$ of $\mathrm{MTH}$, parallel in anterior half and gradually tapering in posterior half, almost reaching tail tip. Tail fins large; UF $28 \%$ of MTH, $28 \%$ of MTH; upper fin extending onto body, SU $96 \%$ of BL, slightly convex; lower fin extending onto body, convex; MTH $80 \%$ of $\mathrm{BH}$, tail tip rounded. Anal tube (Figure 5C) approximately conical, medial, entirely attached to lower fin, opening medial, posteriorly directed. Oral disc (Figure 5D) large, positioned and directed anteroventrally, emarginated, ODW 26\% of BL and $42 \%$ of BW, semicircular without medium notch on the lower labium. Row of papillae at lateral sides of upper labium, 3-4 submarginal papillae, single papilla row on lower labium. No denticulate papillae. One large papilla gap on upper labium, no gap on lower labium, DG $73 \%$ of ODW. Keratodont row formula (KRF) of $1: 2+2 / 1+1: 2$, rows of upper labium unequal, lower rows subequal. Keratodonts (Figure 10B) spoon-shaped bearing 6 large cusps. Jaw sheaths large, black, with fine serrations (Figure $5 \mathrm{D}, 10 \mathrm{~A}$ ); upper sheath shaped as reverse $\mathrm{U}$, with median part dimpled; lower sheath V-shaped, very narrow. Pineal ocellus absent. Lateral line present: first lateral line beginning at margin of mouth, continuing below nares and finishing; second line continuing from midpoint of body to tail.

Coloration. In preservative: body dark brown, ventrum and tail brownish, intestinal spiral ventrally visible through skin. Hind limbs dark ashy grey on dorsum. Tail fin translucent with dark pigmentation. In life: body and tail black to ashy grey, slight pigmentation on ventrum, unpigmented on vent tube. Hindlimbs dark ashy grey on dorsum.

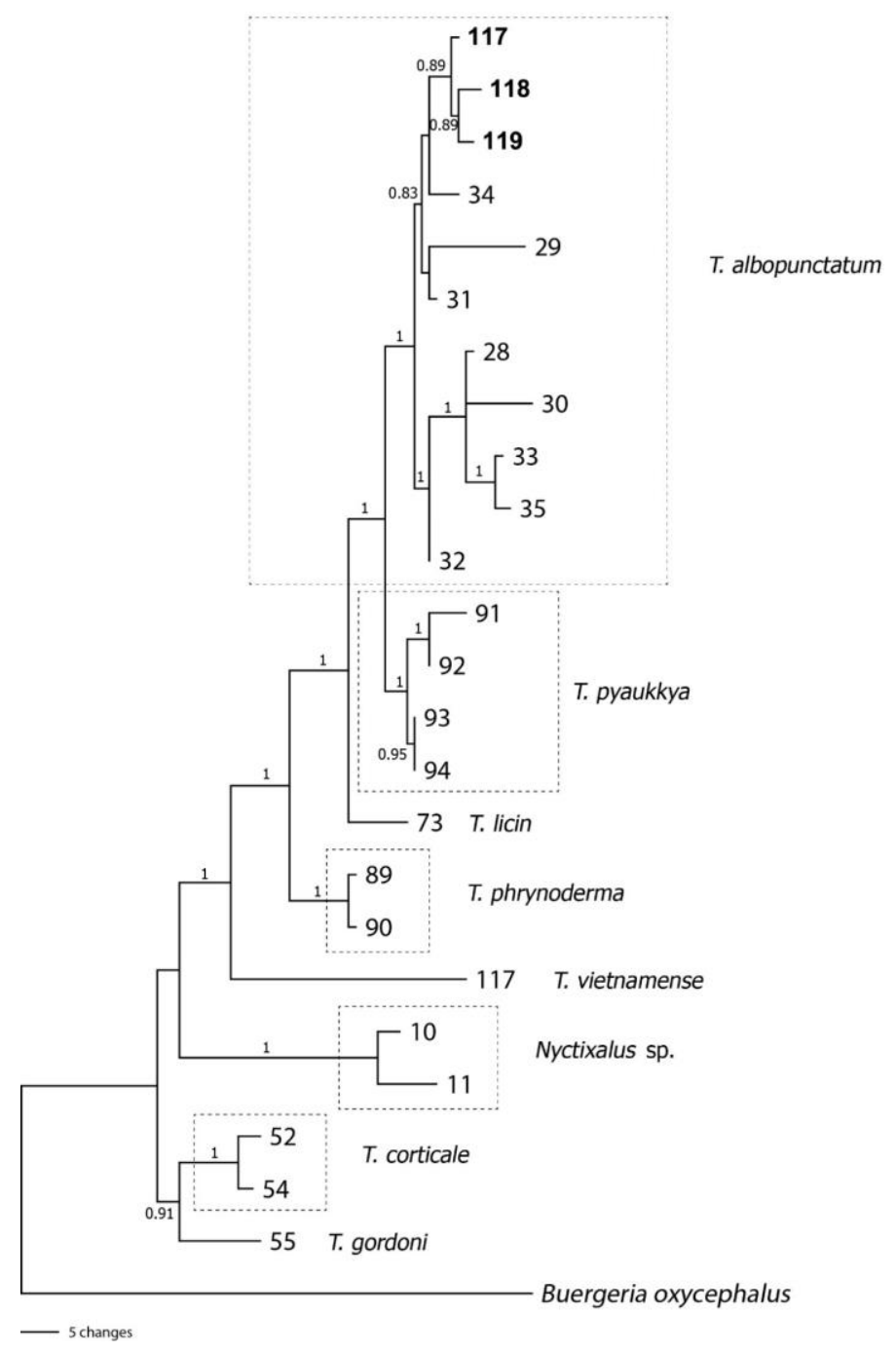

Figure 4. Phylogenetic consensus tree constructed from concatenated DNA sequences of the BDNF, SIA, RHO, and TYR nuclear genes based on Bayesian analysis. Numbers above branches are Bayesian posterior probabilities $\geq 70 \%$. Asterisks indicate Bayesian posterior probabilities $>0.95$. Voucher specimens and GenBank accession numbers are given in the supplementary table (Table S1). Numbers of specimens (No. 1-119) correspond to those in Table S1. The bold numbers of specimens (No. 117-119) indicate new materials from this study 
Table 2. Uncorrected $P$-distance (percentage) between 16S rRNA (below diagonal) and COI (above diagonal) regions of T. albopunctatum species

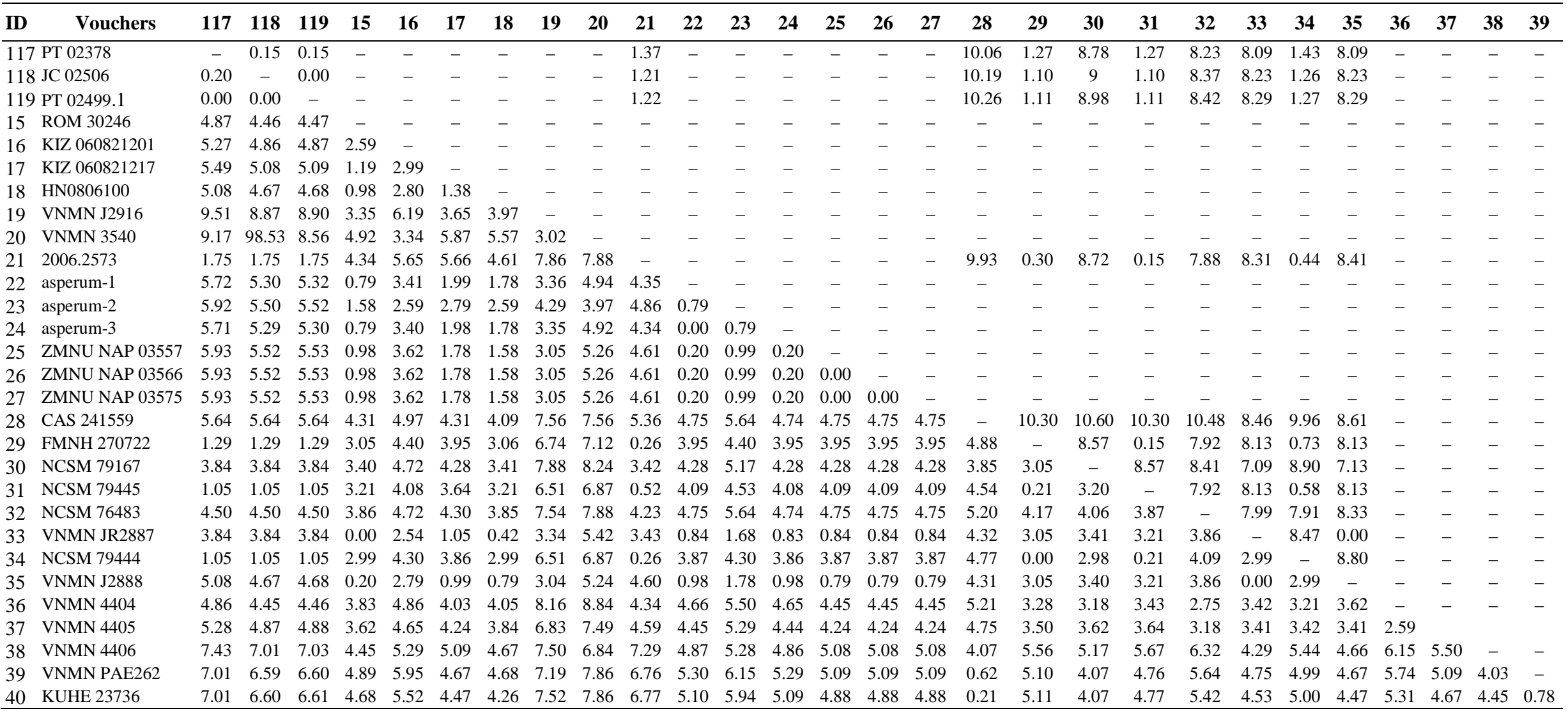


Table 3. Measurements (mm) of T. albopunctatum tadpoles from Phu Luang Wildlife Sanctuary, Loei Province, northeastern Thailand

\begin{tabular}{|c|c|c|c|c|c|c|c|c|c|c|}
\hline & PT02499.1 & PT02499.2 & РT02499.3 & PT02499.4 & PT02499.5 & РT02499.6 & PT02499.7 & PT02499.8 & РT02499.9 & $\begin{array}{c}\text { Average } \pm \text { SD } \\
\text { (min-max) }\end{array}$ \\
\hline Stage & 27 & 37 & 25 & 25 & 25 & 25 & 25 & 25 & 25 & 25 \\
\hline SS & 7.7 & 10.4 & 5.6 & 6.4 & 5.5 & 5.6 & 5.3 & 4.2 & 4.5 & $5.3 \pm 0.74(4.2-6.4)$ \\
\hline SU & 10.9 & 13.2 & 6.2 & 7.1 & 5.9 & 6.4 & 6.5 & 5.1 & 5.1 & $6.0 \pm 0.74(5.1-7.1)$ \\
\hline BL & 11.4 & 15.4 & 6.9 & 7.7 & 6.7 & 7.2 & 7.2 & 5.8 & 5.4 & $6.7 \pm 0.82(5.4-77)$ \\
\hline TAL & $2.7^{*}$ & 25.2 & 11.1 & 13.7 & 9.8 & 12.1 & 11.7 & 10.6 & 9.9 & $11.3 \pm 1.37(9.8-13.7)$ \\
\hline TL & 13.6 & 38.9 & 16.9 & 20.3 & 15.8 & 17.9 & 18.0 & 15.2 & 15.1 & $17.0 \pm 1.87(15.1-20.3)$ \\
\hline UF & 1.3 & 1.5 & 1.3 & 1.3 & 1.8 & 1.5 & 1.0 & 1.0 & 1.2 & $1.3 \pm 0.28(1.0-1.8)$ \\
\hline LF & 1.3 & 1.2 & 1.3 & 1.3 & 1.5 & 1.4 & 0.9 & 1.0 & 1.0 & $1.2 \pm 0.23(0.9-1.5)$ \\
\hline MTH & 4.7 & 6.2 & 4.0 & 4.1 & 4.9 & 4.1 & 3.3 & 3.2 & 3.3 & $3.8 \pm 0.62(3.2-4.9)$ \\
\hline $\mathrm{BH}$ & 5.9 & 7.0 & 3.7 & 4.1 & 3.5 & 3.9 & 3.5 & 3.5 & 3.1 & $3.6 \pm 0.32(3.1-4.1)$ \\
\hline BW & 7.1 & 12.4 & 5.4 & 6.0 & 5.5 & 5.6 & 5.4 & 4.7 & 4.7 & $5.3 \pm 0.48(4.7-6.0)$ \\
\hline $\mathrm{TMH}$ & 2.6 & 4.0 & 1.7 & 1.8 & 1.5 & 1.5 & 1.5 & 1.3 & 1.3 & $1.5 \pm 0.19(1.3-1.8)$ \\
\hline TMW & 2.6 & 4.0 & 0.9 & 1.7 & 1.28 & 1.3 & 1.4 & 1.3 & 1.0 & $1.3 \pm 0.26(0.9-1.7)$ \\
\hline PP & 2.9 & 2.9 & 1.9 & 1.9 & 1.6 & 1.9 & 1.8 & 1.4 & 1.7 & $1.7 \pm 0.19(1.4-1.9)$ \\
\hline $\mathrm{NN}$ & 2.1 & 1.5 & 1.4 & 1.4 & 1.5 & 1.4 & 1.4 & 1.0 & 1.2 & $1.3 \pm 0.17(1.0-1.5)$ \\
\hline $\mathrm{RN}$ & 0.7 & 1.0 & 0.7 & 0.6 & 0.6 & 0.5 & 0.6 & 0.3 & 0.5 & $0.5 \pm 0.13(0.3-0.7)$ \\
\hline NP & 1.7 & 1.1 & 1.1 & 1.3 & 1.2 & 1.2 & 1.2 & 0.9 & 1.1 & $1.1 \pm 0.13(0.9-1.3)$ \\
\hline ED & 0.6 & 1.4 & 0.5 & 0.5 & 0.3 & 0.3 & 0.3 & 0.3 & 0.3 & $0.4 \pm 0.10(0.3-0.5)$ \\
\hline ND & 0.3 & 0.3 & 0.1 & 0.1 & 0.1 & 0.1 & 0.1 & 0.1 & 0.1 & $0.1 \pm 0.0(0.1-0.1)$ \\
\hline SD & 0.8 & 0.6 & 0.6 & 0.8 & 0.6 & 0.5 & 0.6 & 0.4 & 0.5 & $0.6 \pm 0.13(0.4-0.8)$ \\
\hline $\mathrm{AL}$ & 0.4 & 0.5 & 0.3 & 0.2 & 0.2 & 0.2 & 0.2 & 0.1 & 0.2 & $0.2 \pm 0.06(0.1-0.3)$ \\
\hline PL & 0.5 & 0.6 & 0.5 & 0.3 & 0.5 & 0.5 & 0.4 & 0.3 & 0.4 & $0.4 \pm 0.09(0.3-0.5)$ \\
\hline ODW & 3.0 & 3.1 & 1.8 & 1.1 & 1.7 & 1.6 & 1.7 & 1.3 & 1.3 & $1.5 \pm 0.26(1.1-1.8)$ \\
\hline DG & 2.2 & 2.5 & 1.3 & 1.4 & 1.2 & 1.1 & 1.2 & 0.9 & 0.9 & $1.1 \pm 0.19(0.9-1.4)$ \\
\hline KRF & $1: 2+2 / 1+1: 2$ & $1: 2+2 / 1+1: 2$ & $: 1+1 / 1+1: 1$ & $1: 1+1 / 1+1: 1$ & $1: 1+1 / 1+1: 1$ & $1: 1+1 / 1+1$ & $+1 / 1+$ & $: 1+1 / 1+1$ & $+1 / 1+$ & \\
\hline
\end{tabular}

Note: *indicates the cutting tail

\section{Buccal description}

Buccal description is based on $T$. albopunctatum specimen, namely PT 02499.2, Gosner stage 37, TL 25.2 $\mathrm{mm}$, BL $15.4 \mathrm{~mm}$. SEM images of the buccal roof are shown in Figures 6-7. Prenarial arena transverse, arched ridge bearing knobby projections ( 6 anteromedially, 7 and 2 posterolaterally) halfway from beak to nares, sides without papillae. Choanae narrow, parallel to body axis, internarial distance approximately one-third the length of choanae; anterior wall pustular; no papilla on narial valve. Postnarial arena without postnarial papillae. Median ridge transverse elliptical, wider than long, smooth with 10-11 pustolose papillae directed anteromedially, lateral ridge papilla absent. Buccal roof arena oval, rectangular, with 6 buccal roof arena papillae on each side; no papillae within arena; no papillae on anterior esophageal funnel. Posterolateral ridge without papillae. No glandular zone. Dorsal velum continuous, margin curved, medial portion curving toward esophagus.

SEM images of the buccal floor are shown in Figures 8-9. Prelingual arena square; its floor smooth except for a low ridge anterior to tongue anlage bearing two pairs of small papillae. Two pairs of infralabial papillae, anterior pair short with 6 pustules and the next pair long and large separating into two branches with 10-12 pustules. Tongue anlage large oval shaped, bearing 4 lingual papillae, the medial pair long, without pustules, and the lateral pair shorter, without pustules. Buccal floor arena square; medial part covered with small pustules; lateral and posterior parts covered with numerous short papillae; anteromedial to buccal pockets with 4 small papillae. Buccal pockets are elliptical, transverse, distance to tongue anlage larger than that of the medial end of ventral velum. Ventral velum continuous, with spicular support, highly wavy, margin with 25 projections forming a median notch medially. Glottis small. Branchial baskets oblique, longer than wide, 3 filter plates on each side, second filter plate approximately one-half the length of the floor arena.

\section{Discussion}

The results of current study confirmed the phylogeny of Theloderma as reported by Nguyen et al. (2015), Poyarkov et al. (2015), Dever (2017), and Poyarkov et al. (2018). The data supported the separation of T. albopunctatum from the $T$. asperum group, which included $T$. pyaukkya. The morphology of T. albopunctatum specimens from Nam Nao National Park (Phetchabun Province) showed that $T$. pyaukkya was likely to have an opening vocal sac. However, the pairwise distances between these species show deep divergences. The phylogenetic trees constructed from both mtDNA and nuDNA indicated that complexes in the $T$. albopunctatum group showed high genetic differentiation among specimens from Thailand (excluding specimens from Chiang Mai Province) and specimens from Vietnam ( $p$ distance, $6.41 \%$ for $16 \mathrm{~S}$ ); these complexes were more closely related to specimens from Laos ( $p$ distance, $1.85 \%$ for $16 \mathrm{~S}$ ) than to specimens from Myanmar ( $p$ distance, $2.85 \%$ for $16 \mathrm{~S}$ ). 

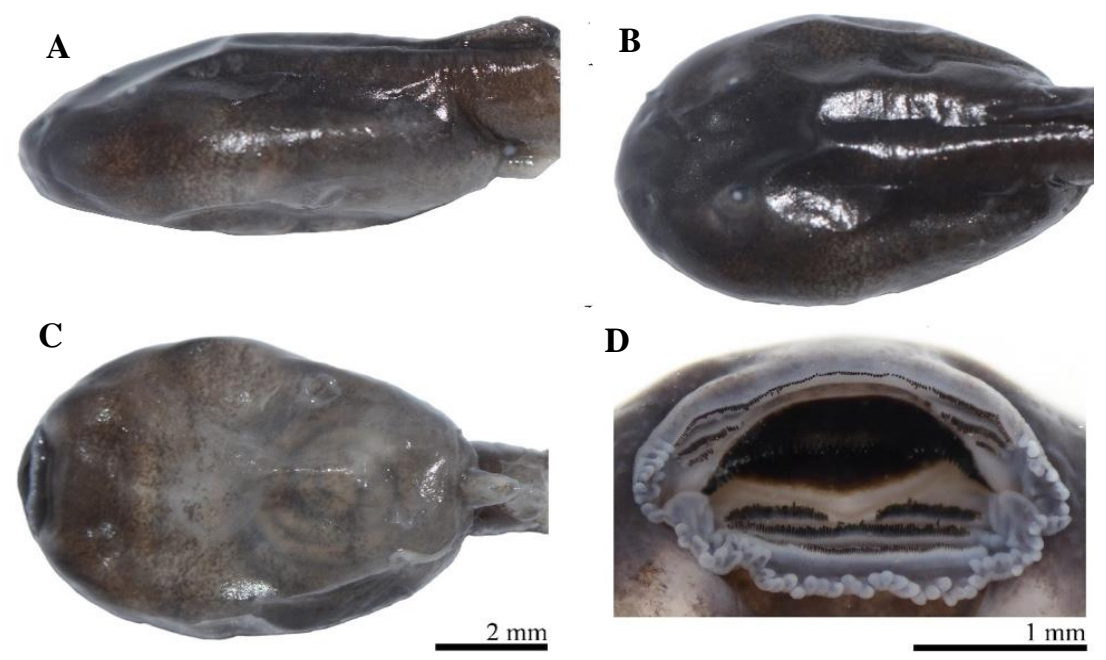

Figure 5. Photograph of T. albopunctatum tadpole (PT 02499.1, Gosner stage 27). A. lateral view, B. dorsal view, C. ventral view, D. oral disc. Scale bar of A, B, and C equal $2 \mathrm{~mm}$
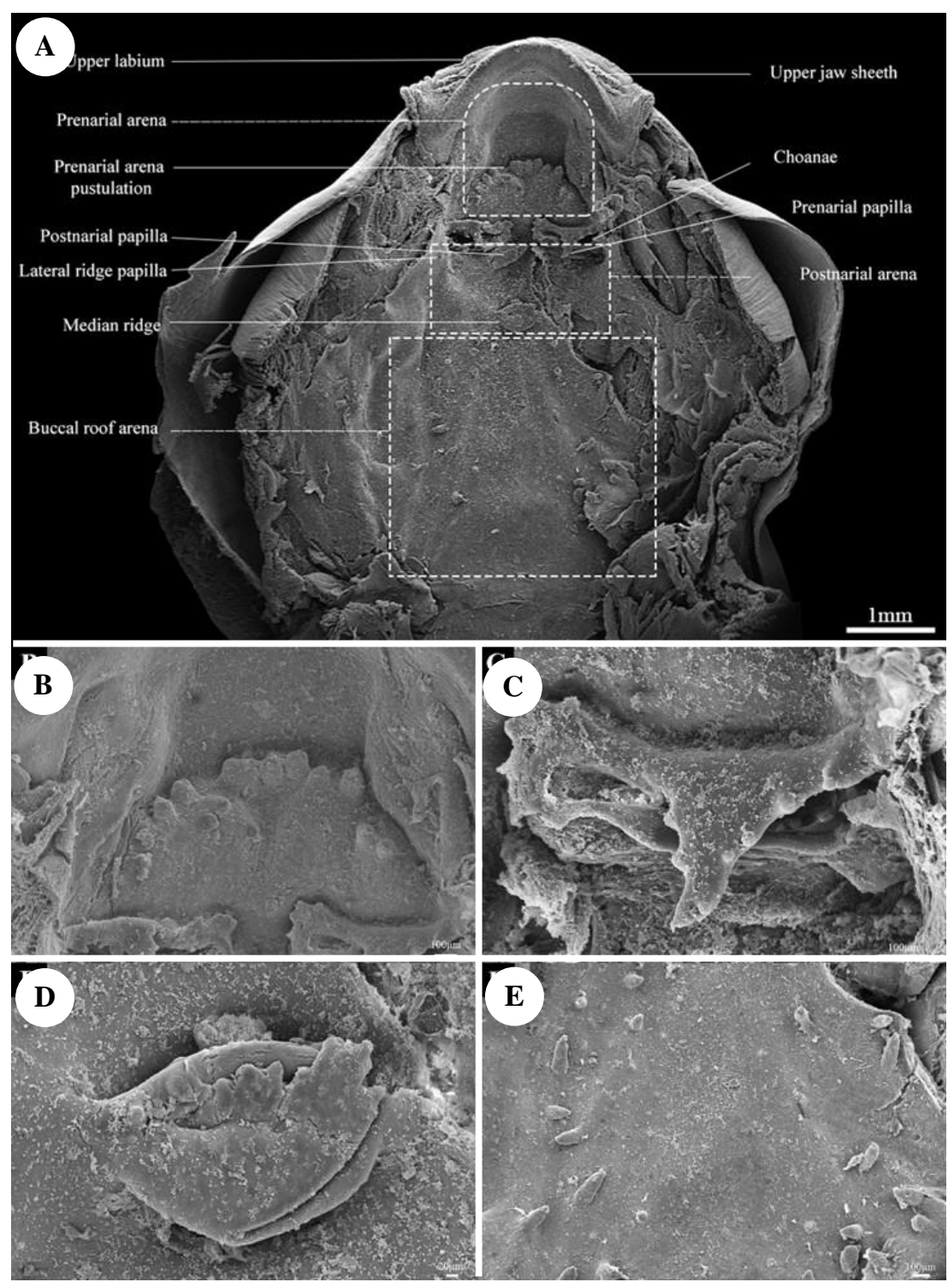

Figure 6. Buccal roof anatomy of T. albopunctatum tadpole (PT 02499.2, Gosner stage 37) under scanning electron microscope (SEM). A. Buccal roof, B. Prenarial arena pustulation, C. Prenarial papilla, D. Middle ridge, E. Lateral ridge papillae on buccal roof arena 

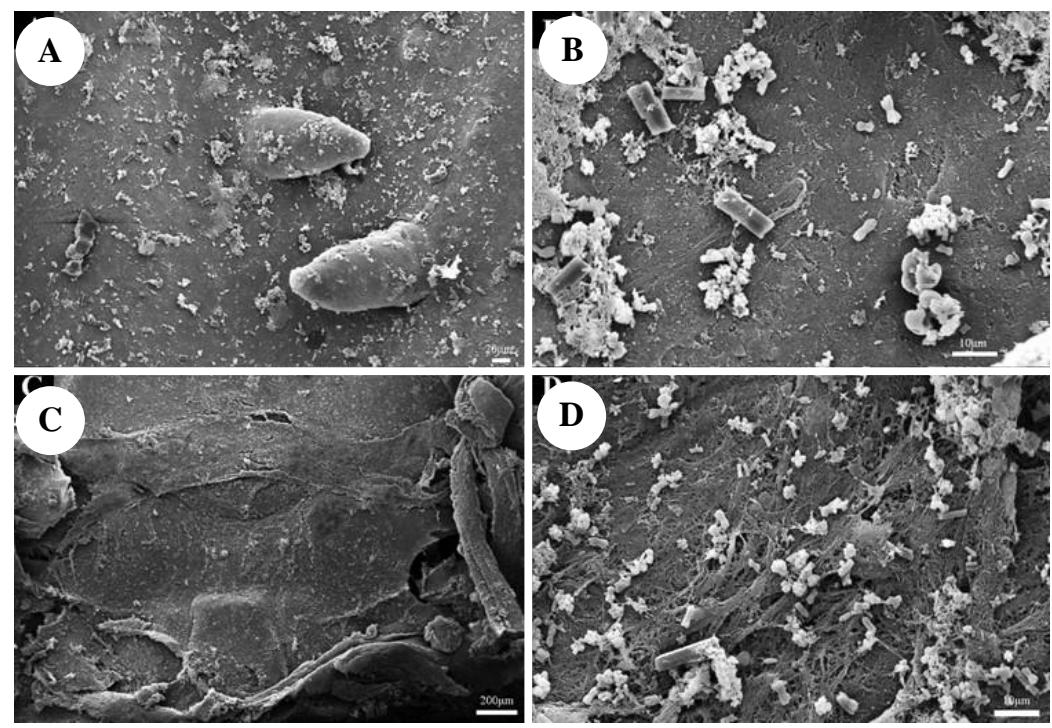

Figure 7. Buccal roof surface of T. albopunctatum tadpole (PT02499.2, Gosner stage 37) under SEM. A. Buccal roof arena surface at magnification 200X, B. Buccal roof arena surface at magnification 1000X, C. Glandular zone surface at magnification 46X, D. Glandular zone surface at magnification 1000X
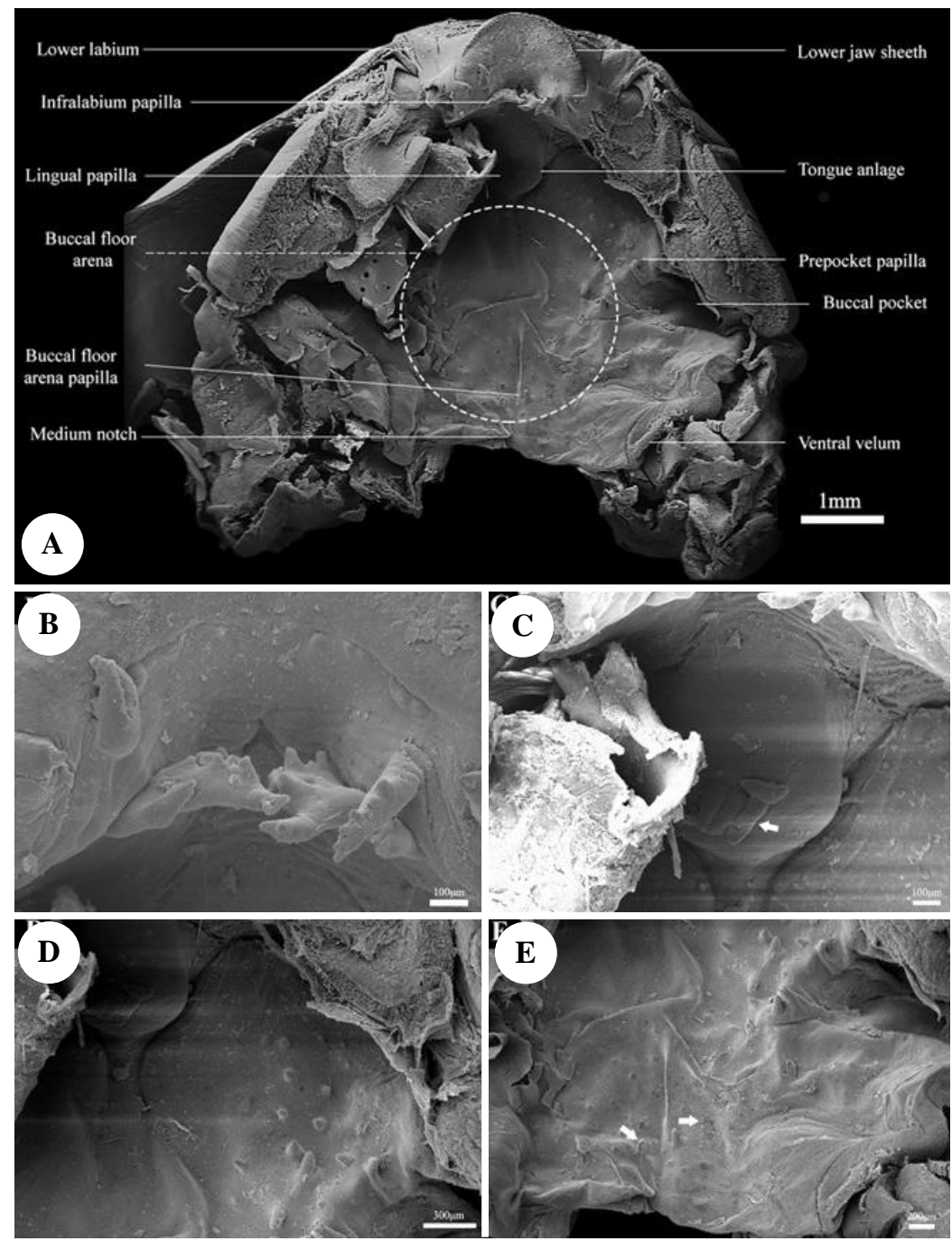

Figure 8. Buccal floor anatomy of T. albopunctatum tadpole (PT 02499.2, Gosner stage 37) under SEM. A. Buccal floor, B. Infralabial papillae, C. Tongue anlage and lingual papilla (white narrow), D. Buccal floor arena papillae on lateral position, E. Buccal floor arena papillae (black narrow) on posterior position 

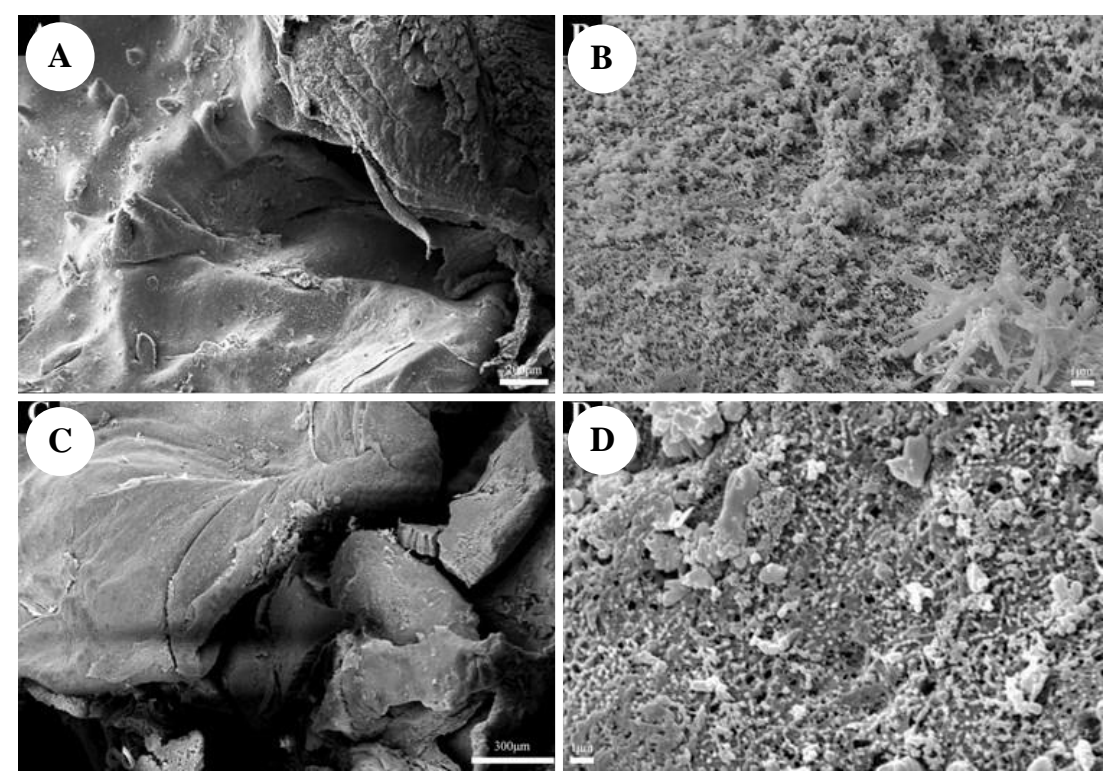

Figure 9. Buccal surface of T. albopunctatum (PT 02499.2, Gosner stage 37) under SEM. A. Buccal pocket surface at magnification 58X, B. Buccal pocket surface at magnification 5000X, C. Ventral velum surface at magnification 58X, D. Ventral velum surface at magnification 5000X
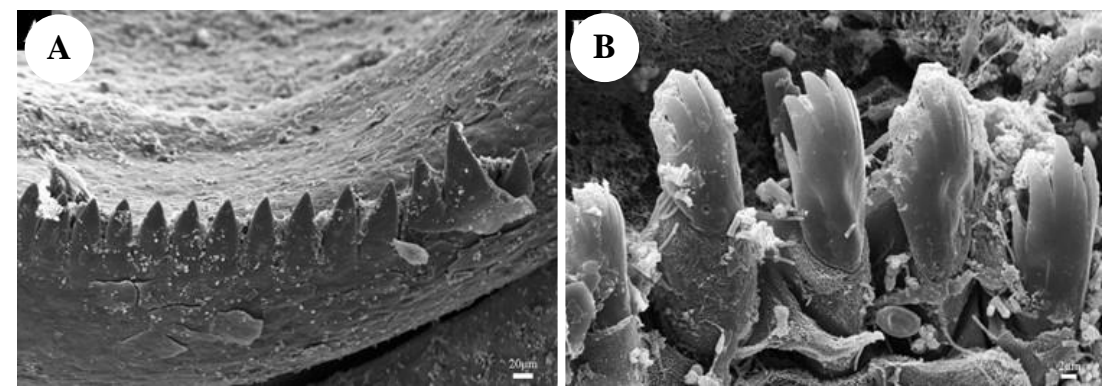

Figure 10. Jaw sheath and labial tooth shape of T. albopunctatum tadpole (PT02499.2, Gosner stage 37) under SEM. A. Upper jaw sheath, B. Lower labial tooth showing spoon-shaped bearing 6 large cusps

Among specimens from Thailand, one individual from Nan Province (northern Thailand) formed a clade with specimens from Loei and Phetchabun Provinces (northeastern Thailand) and from Laos, whereas specimens from Chiang Mai Province formed a clade with specimens from Myanmar and Vietnam. Thus, intraspecific genetic distances among Thailand specimens showed high divergence, with a pairwise distance of $4.42 \%$ for $16 \mathrm{~S}$. These results suggest the possible presence of cryptic species in this region.

Among the 26 known species of genus Theloderma, 12 $(\sim 46 \%)$ species have been described at the tadpole stage, namely T. horridum (Boulenger 1903), T. moloch (Annandale 1912), T. stellatum (Wasserug et al. 1981), T. asperum (Leong and Lim 2003), T. nebulossum (Rowley et al. 2011), T. bambusicolum (Orlov et al. 2012), T. bicolor (Gawor et al. 2012), T. corticale (Gawor et al. 2012), $T$. auratum (Poyarkov et al. 2018), T. gordoni (Kropachev et al. 2018), T. ryabovi (Kropachev et al. 2019), and $T$. vietnamense (Poyarkov et al. 2015). Among the eight Theloderma species reported to occur in Thailand, four
(50\%) species have been described at the tadpole stage, namely $T$. asperum, T. horridum, $T$. stellatum, and $T$. vietnamense, and only one of which ( $T$. stellatum) was described based on specimens from Thailand.

The tadpole stage of T. albopunctatum is similar to the tadpole stages of 12 Theloderma species in terms of general characteristics, such as body shape, eyes, spiracle, vent tube position, jaw sheets shape, and oral disc position. Morphologically, T. albopunctatum tadpoles are most similar to T. asperum tadpoles. However, a single row of marginal papillae on the lower labium of $T$. albopunctatum tadpoles (stages 25, 27, and 37) was found, in contrast to single (stage 24) and double rows (stage 35 ) in T. asperum tadpoles. However, the keratodont row formula (KRF) of T. albopunctatum tadpoles $(1: 1+1 / 1+1: 1$ and $1: 2+2 / 1+1: 2)$ is also similar to $T$. asperum tadpoles $(1: 2+2 / 1+1: 2)$ (Leong and Lim 2003).

The tadpoles of T. horridum, T. moloch, T. stellatum, T. nebulossum, T. bambusicolum, and T. gordoni tadpoles are similar in having numbers of KRF, which is $1: 3+3 / 3$ (Boulenger 1903; Annandale 1912; Wassersug et al. 1981; 
Rowley et al. 2011; Orlov et al. 2012; Kropachev et al. 2018). Thus, the different of KRF maybe distinguished them from T. albopunctatum. The different of KRF also distinguished tadpoles of $T$. albopunctatum from those of T. bicolor of 1:2+2/3 (Gawor et al. 2012), T. corticale of 1:3+3/1+1:2 (Gawor et al. 2012), T. auratum of $2: 3+3 / 3$ (Poyarkov et al. 2018), T. ryabovi of $1: 3+3 / 3,1: 3+3 / 1+1: 2$ (Kropachev et al. 2019), and T. vietnamense of $1: 2+2 / 3$, $1: 3+3 / 3,1: 4+4 / 3$ (Poyarkov et al. 2015).

Theloderma buccal anatomy has remained poorly understood since its description in T. stellatum based on specimens from Thailand (Wassersug et al. 1993). The buccal anatomy of $T$. albopunctatum differs from the anatomy of $T$. stellatum in terms of the following characteristics, i.e., prenarial papillae projection (absent vs. a single long papillae), postnarial arena papillae (one pair of papillae vs. two large papillae), median ridge shape (bulging vs. triangular), prepocket papillae (4 vs. 2-3), and infralabial papilla (two pairs vs. one pair).

Wassersug et al. (1993) suggested that tadpoles of Theloderma species feed on microscopic plankton because they have large brachial baskets, dense gill filters, and weak buccal depressors. Theloderma tadpoles are typically found in tree holes, as well as artificial containers in or near forest habitats (Niyomwan et al. 2019; Makchai et al. 2020). In this study, T. albopunctatum tadpoles were found in artificial containers covered by leaf litter or humus, which resemble tree hole environments.

In conclusion, the present work adds information on tadpole morphology and buccal anatomy to science. The sequences of the tadpole and adults of T. albopunctutatum from PKNNFC have genetic distance varies from $0-0.2 \%$ and $0.15 \%$ for $16 \mathrm{~S}$ and COI, respectively. $T$. albopunctatum tadpoles are medium size, elliptical body depression, and keratodont row formula $1: 2+2 / 1+1: 2$ or $1: 1+1 / 1+1: 1$. Coloration in life is black to ashy gray and fades to dark brown in preservative. Their buccal roof bearing knobby projection on prenarial arena, and internarial distance is approximately one-third of choanae length. Postnarial and lateral papillae are absent on postnarial arena. On buccal roof arena, only six buccal roof arena papillae present on each side. Buccal floor is smooth and has two pairs of infralabial papillae. Tongue anlage is oval with four lingual papillae. Buccal floor arena covers with numerous short papillae.

Because identification of tadpoles is difficult to do in the field or with other identified methods, e.g., rearing to adults and identifying them, comparing with previous description, for instance. Some tadpole descriptions are based on species that may be later found to be a species complex and presently split into several new species. In addition, many species exhibit highly similar in the form of tadpoles and thus correct identification requires more accurate allocation (e.g., molecularly identified) and description. Such previous descriptions need to be revised and corrected, and accurate full descriptions of present species would allow their taxonomic reassessment in the future. According to the present and previous works suggested that the $T$. asperum group required further investigation.

\section{ACKNOWLEDGEMENTS}

We thank Warisa Nampochai, Pannita Wongcha, Nipaporn Chaiyasit, Tiwat Thanwiset, and Sumart Onlamay for their kind assistance during field surveys. We also thank the Department of National Parks, Wildlife and Plant Conservation for granting access to protected areas. This research was partially supported by a research fund for supporting lecturers to allow high-potential students to conduct research in 2019 (Prapaiporn Thongproh and Chantip Chuaynkern), graduate student scholarships from the research capability enhancement program of the Faculty of Science, Khon Kaen University (Jidapa Chunskul and Yodchaiy Chuaynkern), a Faculty of Science Research Grant (2019-2020; Chantip Chuaynkern), and funding from the Research and Graduate studies, Khon Kaen University (Chantip Chuaynkern and Yodchaiy Chuaynkern).

\section{REFERENCES}

Altig R, McDiarmid RW. 1999. Body plan: Development and morphology. In: McDiarmid RW, Altig R (eds) Tadpoles: The Biology of Anuran Larvae. The University of Chicago Press, Chicago.

Annandale N. 1912. Zoological results of the Abor Expedition, 19111912. I. Batrachia. Rec Indian Mus 8: 7-36. DOI: 10.5962/bhl.part.1186

Bain RH, Nguyen TQ, Doan KV. 2009. A new species of the genus Theloderma Tschudi, 1838 (Anura: Rhacophoridae) from northwestern Vietnam. Zootaxa 2191: 58-68. DOI: 10.5281/zenodo. 189385 .

Bonacum J, Desalle R, O'Grady P, Olivera D, Wintermute J, Zilversmit M. 2001. New nuclear and mitochondrial primers for systematics and comparative genomics in Drosophila. Drosoph Inf Serv 84: 201-204.

Bossuyt F, Milinkovitch MC. 2000. Convergent adaptive radiations in Madagascan and Asian ranid frogs reveal covariation between larval and adult traits. Proc Natl Acad Sci USA 97 (12): 6585-6590. DOI: 10.1073/pnas.97.12.6585.

Boulenger GA. 1886. First report on additions to the batrachian collection in the Natural-History Museum. Proc Zool Soc London 1886: 411416.

Boulenger GA. 1903. Report on the batrachians and reptiles. In: Annandale N, Robinson HC (eds.). Fasciculi Malayensis 1903: 131171.

Chuaynkern C, Kaewtongkum N, Duengkae P, Chuaynkern Y. 2019. Tadpoles of Khao Wang frog Humerana miopus (Amphibia, Ranidae): Description of external morphology and buccal anatomy. Maejo Int J Sci Technol 13: 217-230.

Department of National Parks, Wildlife and Plant Conservation. 2014. Diversity and Utilization of Gymnosperm in Phu Khieo-Nam Nao Forest Complex. Forest Herbarium, Forest and Plant Conservation Research Office, Department of National Parks, Wildlife and Plant Conservation. [Thai]

Dever JA. 2017. A new cryptic species of the Theloderma asperum complex (Anura: Rhacophoridae) from Myanmar. J Herpetol 51: 425436. DOI: 10.1670/17-026.

Dever JA, Nguyen H, Wilkinson JA. 2015. Rediscovery and redescription of Theloderma phrynoderma (Ahl, 1927) (Anura: Rhacophoridae) from Myanmar. Copeia 103: 402-415. DOI: 10.1643/CH-14-130.

Division of Information System on Wildlife Conservation. 2020. Department of National Parks, Wildlife and Plant Conservation. http://www.dnp.go.th/wildlife_it/n_web/the_wild/PK_NN.php. [2 March 2021]

Dubois A. 1994. Keratodont formulae in anuran tadpoles: Proposals for a standardization. J Zool Syst Evol Res 32: 297-318. DOI: 10.1111/j.1439-0469.1994.tb00489.x.

Frost DR. 2021. Amphibian Species of the World: An Online Reference. $\begin{array}{llll}\text { Version } & 6.1 \text { Available at: }\end{array}$ 
http://research.amnh.org/herpetology/amphibia/index.html. September 2021]

Gawor A, Chapuis S, Pham CT, Nguyen TQ, Schmitz A, Ziegler T. 2012 Larval morphology of two species of the genus Theloderma (Tschudi, 1838) from Vietnam (Anura: Rhacophoridae: Rhacophorinae). Zootaxa 3395: 59-64. DOI: 10.11646/zootaxa.3395.1.6.

Gosner KL. 1960. A simplified table for staging anuran embryos and larvae with notes on identification. Herpetologica 16: 183-190.

Gouy M, Guindon S, Gascuel O. 2010. SeaView Version 4: A multiplatform graphical user interface for sequence alignment and phylogenetic tree building. Mol Biol Evol 27: 221-224. DOI: 10.1093/molbev/msp259.

Hepperle D. 2011. DNA Dragon 1.4.1. DNA Sequence Contig Assembler Software. Available at: http://dna-dragon.com [23 September 2020]

Kropachev II, Evsyunin AA, Orlov NL, Nguyen TT. 2018 First description of the tadpole of Theloderma gordoni Taylor, 1962 (Anura: Rhacophoridae) from Vietnam. J Herpetol 52: 348-351. DOI: $10.1670 / 17-119$

Kropachev II, Orlov NL, Ostroshabov AA, Nguyen TT. 2019. First description of the tadpole of Theloderma ryabovi Orlov, Dutta, Ghate et Kent, 2006 (Anura: Rhacophoridae), an endemic mossy frog from Vietnam. Zootaxa 4657: 196-200. DOI: 10.11646/zootaxa.4657.1.13.

Leong TM, Lim KK. 2003. Herpetofaunal records from Fraser's Hill, Peninsular Malaysia, with larval descriptions of Limnonectes nitidus and Theloderma asperum (Amphibia: Ranidae and Rhacophoridae). Raffles Bull Zool 51: 123-136.

Li JT, Che J, Bain RH, Zhao EM, Zhang YP. 2008. Molecular phylogeny of Rhacophoridae (Anura): A framework of taxonomic reassignment of species within the genera Aquixalus, Chiromantis, Rhacophorus, and Philautus. Mol Phylogenet Evol 48: 302-312. DOI: 10.1016/j.ympev.2008.03.023.

Li JT, Che J, Murphy RW, Zhao H, Zhao EM, Rao DQ, Zhang, YP. 2009. New insights to the molecular phylogenetics and generic assessment in the Rhacophoridae (Amphibia: Anura) based on five nuclear and three mitochondrial genes, with comments on the evolution of reproduction. Mol Phylogenet Evol 53: 509-522. DOI: 10.1016/j.ympev.2009.06.023.

Li JT, Li Y, Klaus S, Rao DQ, Hillis DM, Zhang YP. 2013 Diversification of rhacophorid frogs provides evidence for accelerated faunal exchange between India and Eurasia during the Oligocene. Proc Natl Acad Sci 110: 3441-3446. DOI: 10.1073/pnas.1300881110.

Liu CC, Hu SQ. 1962. A herpetological report of Kwangsi. Acta Zool Sin 14: 73-104.

Maddison WP, Maddison DR. 2019. Mesquite: A Modular System for Evolutionary Analysis Version 3.61. Mesquite. Available at: http://www.mesquiteproject.org. [23 September 2020]

Makchai S, Chuaynkern Y, Safoowong M, Chuachat C, Cota M. 2020. Amphibians in Northern Thailand. National Science Museum, Pathum Thani.

McLeod DS, Norhayati A. 2007. A new species of Theloderma (Anura: Rhacophoridae) from southern Thailand and peninsular Malaysia. Russ J Herpetol 14: 65-72.

Miller MA, Pfeiffer W, Schwartz T. 2010. Creating the CIPRES Science Gateway for Inference of Large Phylogenetic Trees. Gateway Computing Environments Workshop (GCE) DOI 10.1109/GCE.2010.5676129.

Nguyen TT, Le DT, Nguyen SHL, Matsui M, Nguyen N. 2014. First record of Philautus petilus Stuart and Heatwole, 2004 (Amphibia: Anura: Rhacophoridae) from Vietnam and its phylogenetic position. Curr Herpetol 33: 112-120. DOI: 10.5358/hsj.33.112.

Nguyen TT, Matsui M, Eto K. 2015. Mitochondrial phylogeny of an Asian tree frog genus Theloderma (Anura: Rhacophoridae). Mol Phylogenet Evol 85: 59-67. DOI: 10.1016/j.ympev.2015.02.003.
Nguyen TQ, Pham CT, Nguyen TT, Ngo HH, Ziegler T. 2016 A new species of Theloderma (Amphibia: Anura: Rhacophoridae) from Vietnam. Zootaxa 4168: 171-186. DOI: 10.11646/zootaxa.4168.1.10.

Niyomwan P, Srisom P, Pawangkhanant P. 2019. Amphibians of Thailand. Parbpim, Bangkok. [Thai]

Noonan BP, Chippindale PT. 2006. Dispersal and vicariance: The complex evolutionary history of boid snakes. Mol Phylogenet Evol 40: 347-358. DOI: 10.1016/j.ympev.2006.03.010.

Nylander JAA. 2004. MrModeltest v2. Evolutionary Biology Centre, Uppsala University, Uppsala.

Orlov NL, Poyarkov Jr NA, Vassilieva AB, Ananjeva NB, Nguyen TT, Nguyen NS, Geissler P. 2012. Taxonomic notes on rhacophorid frogs (Rhacophorinae: Rhacophoridae: Anura) of southern part of Annamite Mountains (Truong Son, Vietnam), with description of three new species. Russ J Herpetol 19: 23-64.

Palumbi S, Martin A, Romano S, McMillan WO, Stice L, Grabowski G. 1991. The Simple Fool's Guide to PCR. Version 2. University of Hawaii, Honolulu.

Phusaensri S, Kaewboribut T, Phummisutthigoon S, Kaewtongkum N, Youjaruen M, Tongpun P, Khongcharoensuk H, Nurngsomsri P, Chuaynkern C, Duengkae P, Chuaynkern Y. 2018. Theloderma petilum (Anura, Rhacophoridae): A new country record for Thailand. Alytes 36: 1-4.

Poyarkov Jr, NA, Orlov NL, Moiseeva AV, Pawangkhanant P, Ruangsuwan T, Vassilieva AB, Galoyan EA, Nguyen TT, Gogoleva SS. 2015. Sorting out moss frogs: mtDNA data on taxonomic diversity and phylogenetic relationships of the Indochinese species of the genus Theloderma (Anura, Rhacophoridae). Russ J Herpetol 22: 241-280.

Poyarkov Jr NA, Kropachev II, Gogoleva SS, Orlov NL. 2018. A new species of the genus Theloderma Tschudi, 1838 (Amphibia: Anura: Rhacophoridae) from Tay Nguyen Plateau, central Vietnam. Zool Res 39: $156-180$

Rowley JJL, Le DTT, Hoang HD, Dau VQ, Cao TT. 2011. Two new species of Theloderma (Anura: Rhacophoridae) from Vietnam. Zootaxa 3098: 1-20. DOI: 10.11646/zootaxa.3098.1.1.

Swofford DL. 2019. PAUP*. Phylogenetic Analysis Using PAUP Version 4.0a168 Available at: https://paup.phylosolutions.com/. [23 September 2020]

Taylor EH. 1962. The amphibian fauna of Thailand. Univ Kansas Sci Bull 43: 265-599. DOI: 10.5962/bhl.part.13347.

Wassersug RJ. 1976. Oral morphology of anuran larvae: terminology and general description. Occ Pap Mus Nat Hist Univ Kansas 48: 1-23.

Wassersug RJ, Frogner KJ, Inger RF. 1981. Adaptations for life in tree holes by rhacophorid tadpoles from Thailand. J Herpetol 15: 41-52. DOI: $10.2307 / 1563645$.

Wilkinson JA, Drewes RC. 2000. Character assessment, genus level boundaries, and phylogenetic analysis of the family Rhacophoridae: A review and present day status. Contemp Herpetol 2000: 1-14. DOI: 10.17161/ch.vi1.11961.

Wilkinson JA, Drewes RC, Tatum, OL. 2002. A molecular phylogenetic analysis of the family Rhacophoridae with an emphasis on the Asian and African genera. Mol Phylogenet Evol 2: 265-273. DOI: 10.1016/S1055-7903(02)00212-9.

Yu G, Rao D, Yang J, Zhang M. 2007. Non-monophyly of Rhacophorus rhodopus, Theloderma and Philautus albopunctatus inferred from mitochondrial 16S rRNA gene sequences. Zool Res 28: 437-442.

Yu G, Rao D, Yang J, Zhang M. 2008. Phylogenetic relationships among Rhacophorinae (Rhacophoridae: Anura: Amphibia) with an emphasis on the Chinese species. Zool J Linnean Soc 153: 733-749. DOI: 10.1111/j.1096-3642.2008.00404.x. 
Table S1. Localities, voucher information, and GenBank numbers for all samples used in this study. Classification followed Frost (2021)

\begin{tabular}{|c|c|c|c|c|c|c|c|c|}
\hline Species & Voucher & Localities & $16 S$ & COI & BNBF & RHO & SIA & TYR \\
\hline Buergeria oxycephalus & MVZ 230425 & China: Hainan & KU244359 & KU244459 & KU244396 & KU244313 & KU244427 & KU244357 \\
\hline Liuixalus romeri & $\mathrm{CIB}<\mathrm{CH}>20080048$ & China: Hong Kong & AB871412 & - & - & - & - & - \\
\hline Nasutixalus medogensis & $6255 \mathrm{Rao}$ & China: Motuo, Xizang & GQ285679 & - & - & - & - & - \\
\hline Nyctixalus margaritifer & KUHE 26135 & Indonesia: Java & LC012864 & - & - & - & - & - \\
\hline N. pictus & FMNH 231095 & Malaysia: Sabah, Lahad Datu & DQ283133 & - & - & - & - & - \\
\hline N. pictus & FMNH 231094 & Malaysia: Sabah, Lahad Datu & GQ204726 & - & - & - & - & - \\
\hline N. pictus & KUHE 53517 & Malaysia: Sarawak, Bario & LC012863 & - & - & - & - & - \\
\hline N. pictus & AH07001 & Malaysia: Sarawak, Gunung Mulu & GU154888 & - & - & - & - & - \\
\hline N. pictus & MVZ 239460 & Indonesia: Bengkulu & KU561880 & KU244454 & - & - & - & - \\
\hline Nyctixalus sp. & CAS 247868 & Myanmar: Tanintharyi & KU244380 & KU244457 & KU244403 & KU244314 & KU244424 & KU244355 \\
\hline Nyctixalus sp. & CAS 247498 & Myanmar: Tanintharyi & KU561883 & KU244456 & KU561889 & KU561892 & KU561895 & KU561898 \\
\hline Nyctixalus spinosum & ACA 940 & Indonesia & AF458136 & - & - & - & - & - \\
\hline N. spinosum & Nsp1 & Philippines: Mindanao & KT461916 & - & - & - & - & - \\
\hline N. spinosum & ACD 1043 & Philippines: Mindanao & DQ283114 & - & - & - & - & - \\
\hline T. albopunctatum & ROM 30246 & Vietnam: Tuyen Quang & AF458148 & - & - & - & - & - \\
\hline T. albopunctatum & KIZ 060821201 & China: Yunnan & EF564521 & - & - & - & - & - \\
\hline T. albopunctatum & KIZ 060821217 & China: Guangxi & EF564522 & - & - & - & - & - \\
\hline T. albopunctatum & HN0806100 & China: Hainan & GQ285678 & - & - & - & - & - \\
\hline T. albopunctatum & VNMN J2916 & Vietnam: Vinh Phuc & KJ802913 & - & - & - & - & - \\
\hline T. albopunctatum & VNMN 3540 & Vietnam: Lao Cai & KJ802914 & - & - & - & - & - \\
\hline T. albopunctatum & 2006.2573 & Laos: Luang Phabang & KR828081 & KR087994 & - & - & - & - \\
\hline T. albopunctatum & asperum-1 & Vietnam: Kon Tum & KT461884 & - & - & - & - & - \\
\hline T. albopunctatum & asperum-2 & Vietnam: Kon Tum & KT461908 & - & - & - & - & - \\
\hline T. albopunctatum & asperum-3 & Vietnam: Kon Tum & KT461909 & - & - & - & - & - \\
\hline T. albopunctatum & ZMMU NAP 03557 & Vietnam: Hai Phong & KT461910 & - & - & - & - & - \\
\hline T. albopunctatum & ZMMU NAP 03566 & Vietnam: Hai Phong & KT461911 & - & - & - & - & - \\
\hline T. albopunctatum & ZMMU NAP 03575 & Vietnam: Hai Phong & KT461912 & - & - & - & - & - \\
\hline T. albopunctatum & CAS 241559 & Myanmar: Shan & KU244362 & KU244441 & KU244401 & KU244322 & KU244416 & KU244352 \\
\hline T. albopunctatum & FMNH 270722 & Thailand: Nan & KU244366 & KU244440 & KU244405 & KU244325 & KU244412 & KU244345 \\
\hline T. albopunctatum & NCSM 79167 & Laos: Savannakhet & KU244367 & KU244434 & KU244385 & KU244324 & KU244409 & KU244340 \\
\hline T. albopunctatum & NCSM 79445 & Laos: Luang Phabang & KU244369 & KU244439 & KU244388 & KU244323 & KU244415 & KU244337 \\
\hline T. albopunctatum & NCSM 76483 & Laos: Savannakhet & KU244372 & KU244437 & KU244386 & KU244327 & KU244408 & KU244343 \\
\hline T. albopunctatum & VNMN JR2887 & Vietnam: Tam Dao & KU244375 & KU244431 & KU244381 & KU244318 & KU244407 & KU244338 \\
\hline T. albopunctatum & NCSM 79444 & Laos: Luang Phabang & KU244379 & KU244438 & KU244387 & KU244326 & KU244414 & KU244347 \\
\hline T. albopunctatum & VNMN JR2888 & Vietnam: Tam Dao & LC012853 & KU244432 & KU244382 & KU244319 & KU244406 & KU244351 \\
\hline T. albopunctatum & VNMN 4404 & Vietnam: Kon Tum & LC012854 & - & - & - & - & - \\
\hline T. albopunctatum & VNMN 4405 & Vietnam: Gia Lai & LC012855 & - & - & - & - & - \\
\hline T. albopunctatum & VNMN 4406 & Vietnam: Than Hoa & LC012856 & - & - & - & - & - \\
\hline T. albopunctatum & VNMN PAE 262 & Vietnam: San La & LC012857 & - & _- & - & - & _- \\
\hline
\end{tabular}




\begin{tabular}{|c|c|c|c|c|c|c|c|c|}
\hline T. albopunctatum & KUHE 23736 & Thailand: Doi Changdao & LC012858 & - & - & - & - & - \\
\hline T. asperum & ZRC1.1.9321 & Malaysia: Fraser Hill & GQ204725 & - & - & - & - & - \\
\hline T. asperum & pet trade & Malaysia: Perak & KT461929 & - & - & - & - & - \\
\hline T. bicolor & MNHN 1999.5986 & Vietnam & AY880529 & - & - & - & - & - \\
\hline T. bicolor & IEBR A.20011.4 & Vietnam: Lao Cai & JX046474 & - & - & - & - & - \\
\hline T. bicolor & VNMN 1394 & Vietnam: Lao Cai & JX046475 & - & - & - & - & - \\
\hline T. bicolor & Tbic3 & Vietnam: Ninhbinh & KT461899 & - & - & - & - & - \\
\hline T. bicolor & Tbic2 & Vietnam: Ninhbinh & KT461923 & - & - & - & - & - \\
\hline T. corticale & AMNH A161499 & Vietnam: Vinh Phu & DQ283050 & - & - & - & - & - \\
\hline T. corticale & VNMN J2892 & Vietnam: Tuyen Quang & KJ802916 & - & - & - & - & - \\
\hline T. corticale & Tcort1 & Vietnam: Ninhbinh & KT461885 & - & - & - & - & - \\
\hline T. corticale & Tcort 2 & Vietnam: Ninhbinh & KT461886 & - & - & - & - & - \\
\hline T. corticale & MVZ 223905 & Vietnam: Tam Dao & KU244364 & KU244452 & KU244393 & KU244316 & KU244417 & KU244354 \\
\hline T. corticale & VNMN 3556 & Vietnam: Tam Dao & LC012841 & - & - & - & - & - \\
\hline T. corticale & MVZ 225131 & Vietnam: Tam Dao & KU244365 & KU244453 & KU244394 & KU244315 & KU244420 & KU244353 \\
\hline T. gordoni & MVZ 226469 & Vietnam: Tam Dao & KU244363 & KU244451 & KU244395 & KU244334 & KU244423 & KU244358 \\
\hline T. gordoni & VNMN 4407 & Vietnam: Kon Tum & LC012852 & & & & & \\
\hline T. horridum & KUHE 52582 & Malaysia: Negeri Sembilan, Kenaboi & LC012861 & - & - & - & - & - \\
\hline T. horridum & ZMMU NAP 04015 & Thailand: Satun & KT461890 & - & - & - & - & - \\
\hline T. laeve & ZNMU NAP 02906 & Vietnam: Binh Phuoc & KT461883 & - & - & - & - & - \\
\hline T. laeve & ZNMU NAP 02907 & Vietnam: Binh Phuoc & KT461905 & - & - & - & - & - \\
\hline T. laeve & ZNMU NAP 02908 & Vietnam: Binh Phuoc & KT461906 & - & - & - & - & - \\
\hline T. laeve & ZNMU NAP 01644 & Vietnam: Lam Dong & KT461907 & - & - & - & - & - \\
\hline T. laeve & ZNMU NAP 01645 & Vietnam: Lam Dong & KT461913 & - & - & - & - & - \\
\hline T. lateriticum & AMNH 168757 & Vietnam, Lao Cai, SaPa & LC012848 & - & - & - & - & - \\
\hline T. lateriticum & VNMN PAE 226 & Vietnam: Son La & LC012849 & - & - & - & - & - \\
\hline T. lateriticum & VNMN 1215 & Vietnam: Bac Giang, Yen Tu & LC012850 & - & - & - & - & - \\
\hline T. lateriticum & VNMN 1216 & Vietnam: Bac Giang, Yen Tu & LC012851 & - & - & - & - & - \\
\hline T. leporosum & KUHE 52581 & Malaysia: Kenaboi & AB847128 & - & - & - & - & - \\
\hline T. leporosum & LJT W46 & Malaysia & KC465841 & - & - & - & - & - \\
\hline T. leporosum & Tlep1 & Malaysia: Selangor & KT461922 & - & - & - & - & - \\
\hline T. licin & KUHE 19426 & Thailand: Nakon Sri Tamarat & LC012859 & - & - & - & - & - \\
\hline T. licin & KUHE 52599 & Malaysia: Selangor & KJ802920 & - & - & - & - & - \\
\hline T. licin & MVZ 272184 & Indonesia & KU244368 & KU244447 & KU244384 & KU244333 & KU244425 & KU244346 \\
\hline T. moloch & SDBDU 2011.345 & Arunachal Pradesh, India & KU169993 & - & - & - & - & - \\
\hline T. moloch & YPX31941 & China: Medog, Tibet & KU243081 & - & - & - & - & - \\
\hline T. nebulosum & AMS R 173409 & Vietnam: Kon Tum & JN688168 & - & - & - & - & - \\
\hline T. nebulosum & AMS R173877 & Vietnam: Kon Tum & JN688169 & - & - & - & - & - \\
\hline T. nebulosum & ROM 39588 & Vietnam: Kon Tum & KT461887 & - & - & - & - & - \\
\hline T. nebulosum & VNMN ROM 39588 & Vietnam & LC012845 & - & - & - & - & - \\
\hline T. palliatum & AMS R 173130 & Vietnam: Lam Dong & JN688172 & - & - & - & - & - \\
\hline T. palliatum & AMS R 173131 & Vietnam: Lam Dong & JN688173 & - & - & - & - & - \\
\hline T. palliatum & ZMMU NAP 02511 & Vietnam: Lam Dong & KT461902 & - & - & - & - & - \\
\hline
\end{tabular}




\begin{tabular}{|c|c|c|c|c|c|c|c|c|}
\hline T. palliatum & ZMMU NAP 02516 & Vietnam: Lam Dong & KT461903 & - & - & - & - & - \\
\hline T. palliatum & ZMMU NAP 02735 & Vietnam: Dak Lak & KT461926 & - & - & - & - & - \\
\hline T. palliatum & ZMMU NAP 02736 & Vietnam: Dak Lak & KT461927 & - & - & - & - & - \\
\hline T. palliatum & ZMMU NAP 02756 & Vietnam: Dak Lak & KT461930 & - & - & - & - & - \\
\hline T. palliatum & VNMN NAP 2735 & Vietnam: Dak Lak & LC012843 & - & - & - & - & - \\
\hline T. palliatum & VNMN NAP 2736 & Vietnam: Dak Lak & LCO12844 & - & - & - & - & - \\
\hline T. phrynoderma & CAS 243920 & Myanmar: Tanintharyi & $\mathrm{KJ} 128282$ & KU244448 & KU244402 & KJ128278 & KU244410 & KJ128276 \\
\hline T. phrynoderma & CAS 247910 & Myanmar: Tanintharyi & KJ128283 & KU244449 & KU244404 & KJ128279 & KU244411 & KJ128277 \\
\hline T. pyaukkya & CAS 226113 & Myanmar: Kachin & KU244361 & KU244443 & KU244399 & KU244331 & KU244421 & KU244339 \\
\hline T. pyaukkya & CAS 236133 & Myanmar: Kachin & KU244360 & KU244444 & KU244400 & KU244330 & KU244419 & KU24434 \\
\hline T. pyaukkya & CAS 234869 & Myanmar: Chin & KU244370 & KU244445 & KU244398 & KU244332 & KU244418 & KU244342 \\
\hline T. pyaukkya & CAS 234857 & Myanmar: Chin & KU244371 & KU244446 & KU244397 & KU244329 & KU244426 & KU244341 \\
\hline T. rhododiscus & AMNH A163893 & Vietnam: Ha Giang, Vi Xuyen & DQ283393 & - & - & - & - & - \\
\hline T. rhododiscus & KIZ 060821063 & China: Guangxi & DQ283393 & - & - & - & - & - \\
\hline T. rhododiscus & KIZ 060821170 & China: Guangxi & EF564534 & - & - & - & - & - \\
\hline T. rhododiscus & SCUM 061192L & China: Mt. Dayao, Guangxi & EU215530 & - & - & - & - & - \\
\hline T. rhododiscus & $\mathrm{CIB}<\mathrm{CH}>\mathrm{GX} 200807017$ & China: Guangxi & LC012842 & - & - & - & - & - \\
\hline T. ryabovi & VNMN 3924 & Vietnam: Kon Tum, Mang Canh & LC012860 & - & - & - & - & - \\
\hline T. ryabovi & ryabovi-1 & Vietnam: Kon Tum & KT461914 & - & - & - & - & - \\
\hline T. ryabovi & ryabovi-2 & Vietnam: Kon Tum & KT461915 & - & - & - & - & - \\
\hline Theloderma sp. & VNMN 4403 & Vietnam: Gia Lai & LC012846 & - & - & - & - & - \\
\hline T. stellatum & NAP03961 & Thailand: Nakhonnayok & KT461917 & - & - & - & - & - \\
\hline T. truongsonense & ROM 39363 & Vietnam: Quang Binh & KT461925 & - & - & - & - & - \\
\hline T. truongsonense & VNMN 4402 & Vietnam: Khanh Hoa & LC012847 & - & - & - & - & - \\
\hline T. vietnamense & AMS R 173283 & Vietnam: Binh Thuan & JN688170 & - & - & - & - & - \\
\hline T. vietnamense & AMS R 147047 & Cambodia: Mondol Kiri & JN688171 & KU244460 & KU244391 & KU244335 & - & KU244356 \\
\hline T. vietnamense & ZMMU NAP 03724 & Vietnam: Kien Giang & KT461888 & - & - & - & - & - \\
\hline T. vietnamense & NAP03723 & Vietnam: Kien Giang & KT461919 & - & - & - & - & - \\
\hline T. vietnamense & ZMMU NAP 03680 & Vietnam: Tay Ninh & KT461921 & - & - & - & - & - \\
\hline T. vietnamense & KUHE 22065 & Thailand, MaeYom & LC012862 & - & - & - & - & - \\
\hline T. vietnamense & FMNH 267765 & Cambodia: Koh Kong & KU561885 & KU244462 & - & - & - & - \\
\hline T. vietnamense & FMNH 262786 & Cambodia: Mondolkiri & KU561884 & KU244461 & - & - & - & - \\
\hline T. vietnamense & NCSM 76490 & Laos: Savannakhet & KU561886 & KU244464 & - & - & - & - \\
\hline T. vietnamense & NCSM 80384 & Vietnam: Binh Thuan & KU561887 & KU244463 & KU561888 & KU561891 & KU561894 & KU561897 \\
\hline T. albopunctatum & PT 02378 & Thailand: Phetchabun, Nam Nao NP & MW648779 & MW648785 & MW648776 & MW648782 & MW648788 & MW648779 \\
\hline T. albopunctatum & JC 02506 & Thailand: Loei, Phu Luang WS & MW648780 & MW648786 & MW648777 & MW648783 & MW648789 & MW648780 \\
\hline T. albopunctatum & PT 02499.1 & Thailand: Loei, Phu Luang WS & MW648781 & MW648787 & MW648778 & MW648784 & MW648790 & MW648781 \\
\hline
\end{tabular}

